UNIVERSIDADE DE SÃO PAULO

INSTITUTO DE GEOCIÊNCIAS

\title{
AVALIAÇÃO DOS TEORES DE CARBONO ORGÂNICO TOTAL E ASPECTOS COMPOSICIONAIS DOS FOLHELHOS DEVONIANOS DA FORMAÇÃO LONGÁ, BACIA DO PARNAÍBA, BRASIL
}

\author{
Yohana Villafañez Cardona
}

Orientador: Prof. Dr. Claudio Riccomini

\author{
DISSERTAÇÃO DE MESTRADO
}

Programa de Pós-Graduação em Geoquímica e Geotectônica

SÃO PAULO

2015 
"Los científicos dicen que estamos hechos de átomos pero a mí un pajarito me contó que estamos hechos de historias" 


\section{Agradecimentos}

Inicialmente, eu gostaria de agradecer este maravilhoso país pela oportunidade de conhecê-lo, explorá-lo, estudá-lo e por compartilhar experiências com sua gente. Obrigado pelos seus ritmos musicais. Obrigado Brasil, país maravilhoso. Que rico país.

Agradeço ao professor Claudio Riccomini, quem foi meu orientador, fico grata com você por abrir as portas a novos conhecimentos, por abrir as portas do IGc e o IEE para mim. Obrigada pela ajuda, pela paciência durante todo o desenvolvimento deste trabalho. Prezado professor, muito obrigada.

Ao Prof. Dr. Carlos Henrique Grohmann por o acompanhamento nas atividades de campo e ao geólogo Marlei A.C. Chamani pelas discussões, ideas e acompanhamento nos levantamentos de campo. Aos Profs. Drs. Álvaro Penteado Crósta e Marcos Alberto Rodrigues Vasconcelos pela cessão da amostra de folhelho de testemunho de sondagem na Cratera de Serra da Cangalha. Ao Prof. Dr. Renato Paes de Almeida e geólogo, MSc, Marlei A.C. Chamani pela cessão de amostras de folhelho das formações Tianguá e Longá.

Ao Dr. Flávio Machado de Sousa Carvalho (IGc-USP) pelo auxílio nas análises por difração de raios X. Ao Dr. Isaac Jamil Sayeg (IGc-USP) pelo auxílio nas análises por microscopia eletrônica de varredura. À Erika Jeanette Malo Millanao (IEE-USP) pelo auxílio na preparação de amostras, pelos cafés e aquelas bolachas gostosas no final do dia. À Profa. Dra. Lucy Gomes Sant'Anna (IEE e EACH-USP) pela orientação na preparação de amostras, execução das análises e interpretação dos resultados de difração de raios $\mathrm{X}$ e de microscopia eletrônica de varredura.

Aos professores com que tive o privilégio de compartir e apreender, Prof. Dr. Renato Paes de Almeida, Prof. Prof. Dr. Paulo Giannini, Prof. Dr. Paulo Roberto Dos Santos, Prof. Dr. Setembrino Petri, Profa. Dra. Lucy Gomes Sant'Anna e Profa. Dra. Rosa Maria Silveira Bello

Ao Programa de Pós-Graduação em Geologia Sedimentar, Instituto de Geociências, Universidade de São Paulo.

Aos funcionários do IGc-USP especialmente a seção de biblioteca, pessoal de segurança, todas as meninas da limpeza e especialmente ao meu "Toñito" e André 
À Coordenação de Aperfeiçoamento de Pessoal de Nível Superior (CAPES), pela concessão de bolsa de estudos,

Ao Conselho Nacional de Desenvolvimento Científico e Tecnológico (CNPq, processo 307871/2010-0), ao Instituto de Energia e Ambiente, Universidade de São Paulo (IEE-USP) e à Financiadora de Estudos e Projetos (FINEP, projeto Ref. 1452/13) pelos recursos financeiros.

A mis queridos amigos que han compartido conmigo estos dos años de vida, recuerdos, miles de chocho-aventuras y momentos inolvidables. Amigos que me trajo el amor, el estudio y que ahora hacen parte de mi familia, a los que por circunstancias de la vida se van de nuestro lado a un lugar lejano. A esos amigos a los que necesitamos cerca. Duele decirles adiós porque eso significa kilómetros; pero siempre serán mi Tropicombo (unidos por un país). A mis parceras del alma: Verónica, Valentina (y Jairo), Maria Cuca, Ginneth Pulido Gómez (mi morena) y mi pequeño gran amigo Tomás Mora Pulido. A los pio pio de mamá (A y S). A Santi León, negrito gracias. A Cleber por iluminar... y a Claudio Alejandro. A Lazaro por su baile y sus risotadas, al igual que a su familia Gladis y Juan David. Queridos amigos nos queda la amistad para ir convirtiendo la vida en una geografía vivible.

A mis compañeros Diego, Santiago, Cristian, Pedro, Daniel, Maria Isabel, Thaís Trevissani, Glaucia (Clô) y Vanessa. Al hoy profesor Carlos Mario por la paciencia, la ayuda, los consejos y orientaciones.

Á familia colombo-brasilera do 134b, Eveline, Jaqueline, Fabiano, Rafa, Oscar y Tuco. Al Prof. Dr. Andrés Bustamante y su familia por haberme acogido durante mis primeros días de nuevos comienzos en este país.

A la Guapa y mi papá porque aunque $6000 \mathrm{~km}$ nos separan, nuestro amor se hace cada día más fuerte, los amo papás. A mi alma gemela, compañero de viaje y mi super parcero que desde el cielo siempre me acompaña.

A vos, Laura Román García, porque nada de esto ha sido en vano. Estamos juntas en esto.

A ti, por lo afortunada que fuiste de haber tenido maestros tan generosos, por tus parceros-hermanos tan amorosos y tan cómplices. Se me estarán pasando personas a quien darle las gracias, pero sepan que estoy infinitamente agradecida. 


\section{Resumo}

Este trabalho teve como objetivo avaliar a distribuição do carbono orgânico total e, secundariamente, o estudo mineralógico dos folhelhos devonianos da Formação Longá, bem como suas relações com sedimentação, tectonismo e magmatismo na Bacia do Parnaíba.

Os folhelhos da Formação Longá são principalmente rítmicos, em lâminas alternadas com arenitos, e apresentam composições mineralógicas distintas nas faixas leste e oeste de afloramentos da bacia. Na faixa leste, os folhelhos contêm quartzo, , mica e clorita detríticos, calcita, dolomita e hematita, e albita autigênica. Na faixa oeste são compostos por feldspato potássico e caulinita, provavelmente detrítico e intempérica, respectivamente, além de quartzo, mica e clorita detríticos, argilomineral interestratificado illita/smectita e calcita. O quartzo não foi detectado em algumas amostras das faixas leste e oeste de afloramentos. A autigênese da albita pode estar relacionada com atividade magmática da Formação Sardinha, por efeito térmico e/ou de circulação de fluídos, ou ainda resultar da substituição de feldspato potássico por soterramento, que teria sido maior na parte leste da Bacia do Parnaíba.

As amostras de folhelhos da Formação Longá analisadas apresentaram teores de COT muito baixos para serem consideradas como geradoras de hidrocarbonetos. $\mathrm{Na}$ faixa de afloramentos leste da Bacia do Parnaíba os folhelhos apresentaram valores de COT entre $0,33 \%$ e $0,02 \%$, enquanto que na faixa de afloramentos da parte oeste da bacia os teores de COT variaram entre $0,61 \%$ e $0,05 \%$. As variações nos teores podem estar relacionadas com a composição original do sedimento ou grau de intemperismo. Não há relação evidente entre os teores de COT e a proximidade de rochas básicas intrusivas, mas as amostras com teores mais baixos encontram-se na área de influência do Lineamento Transbrasiliano.

Os folhelhos da Formação Pimenteiras estudados na borda oeste da bacia compõem pacotes de espessura métrica e são compostos por albita, mica, caulinita calcita e dolomita. O quartzo não foi detectado. A presença de pirita detrítica indica a vigência de condições anóxicas durante a deposição. Os valores de COT obtidos em amostras de folhelhos de folhelhos da Formação Pimenteiras, coletadas na faixa oeste de afloramentos, variaram de $0,68 \%$ a $1,55 \%$, muito inferiores aos valores de $2 \%$ a até 
$6 \%$ reportados para a parte leste da bacia. Os menores teores da faixa oeste podem estar relacionados com a proximidade do Lineamento Transbrasiliano.

A natureza siliciclástica dos folhelhos da Formação Longá mostra uma origem a partir de porções emersas do Gondwana que estavam sendo erodidas durante a deposição, a qual teria ocorrido sob clima temperado, em ambiente nerítico. As mudanças climáticas certamente afetaram a produção de biomassa e consequentemente a quantidade de matéria orgânica presente nos folhelhos das formações devonianas estudadas.

Os dados obtidos neste trabalho representam uma abordagem inicial da distribuição do carbono orgânico total e da composição dos folhelhos da Formação Longá. Há recorrência vertical dos níveis de folhelhos, com diferentes teores de COT, bem como variações laterais desses teores. Desta forma, a melhor avaliação da Formação Longá requer estudos de detalhe com controle estratigráfico mais detalhado. 


\begin{abstract}
The main objective of this work was to evaluate the distribution of total organic carbon content (TOC) and secondarily the composition of shale of the Devonian Longá Formation in the Parnaíba Basin, Brazil. The possible relationship of TOC and shale composition in relation to the sedimentation, tectonics and magmatism in this basin were also analyzed.
\end{abstract}

The shales of Longá Formation are rythmically interbedded with thin layers of sandstone and present different compositions in the east and west outcrop belts in the basin. To the east they include detrital quartz, mica and chlorite, calcite, dolomite and hematite, and authigenic albite. To the west they have detrital K-feldspar, quartz, mica and chlorite, I/S interestratified clay minerals, kaolinite and calcite. Quartz is absent in some samples from eastern and western parts of the basin. Albite authigenesis was probably related to the thermal effect and/or fluid circulation during Late Cretaceous magmatic activity or to the K-feldspar substitution with burial, the eastern part of the basin being subject to deeper burial.

The analyzed samples of shales from the Longá Formation show very low TOC values to be considered as hydrocarbon source rocks. In the eastern outcrop belt in the Parnaíba Basin the TOC values range from $0.33 \%$ to $0.02 \%$, whilst in the western belt range from $0.61 \%$ e $0.05 \%$. TOC content variations can be related to the original composition of the sediments or to the weathering degree. There is no clear relationship between TOC values and the proximity of intrusive bodies. Nevertheless, samples with low TOC content are within the zone of influence of the Transbrasiliano Lineament.

The shales of the Devonian Pimenteiras Formation observed in the western part of the basin occurs as metric packs and are composed of mica, chlorite, kaolinite, calcite, dolomite and authigenic albite. Quartz is absent in all samples. The presence of detrital pyrite indicates anoxic conditions during deposition. TOC content in samples of shales from western outcrop belt of the Pimenteiras Formation in the Parnaíba Basin show values ranging from $0.68 \%$ to $1.55 \%$, which are much less than the values of $2 \%$ up to $6 \%$ reported to the eastern part of the basin. The lower TOC values can be related to the zone of influence of the Transbrasiliano Lineament. 
The siliciclastic nature of shales of the Longá Formation indicates an origin by erosion of emerged lands of Gondwana. The deposition would have occurred under a temperate paleoclimate, in a neritic environment. Climate change certainly affected biomass production and consequently the organic matter content in shales of studied Devonian formations.

The results of this study represent a first approach to understand the distribution of TOC content and mineralogical composition of shales of Longá Formation. There is vertical recurrence of shales with different TOC content as well as lateral variations in this content. Thus, a better evaluation of Longá Formation requires more detailed studies with stratigraphic control. 


\section{CONTEÚDO}

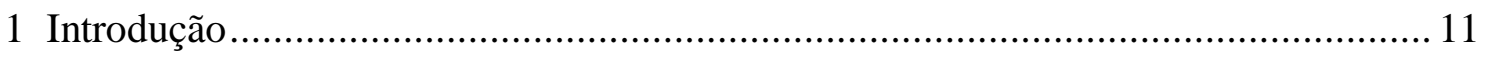

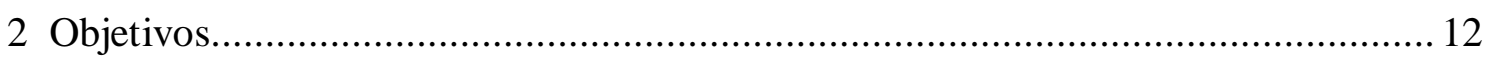

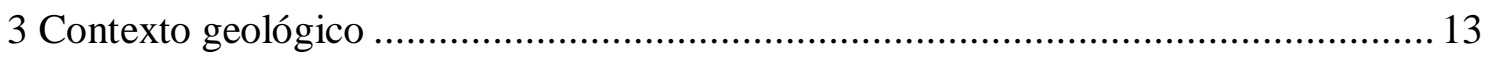

3.1 Estratigrafia da Bacia do Parnaíba ............................................................... 13

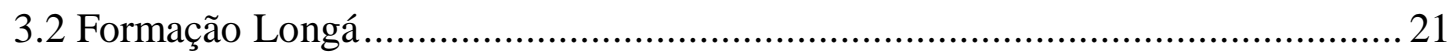

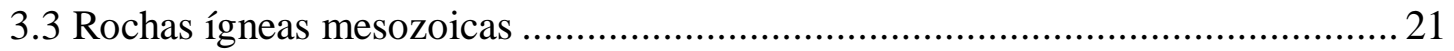

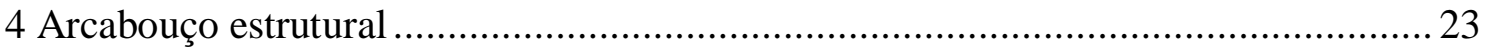

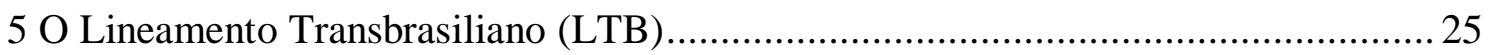

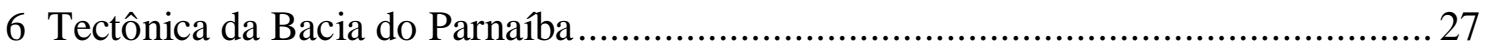

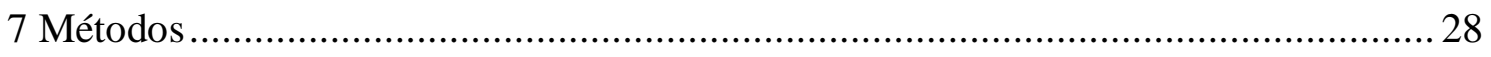

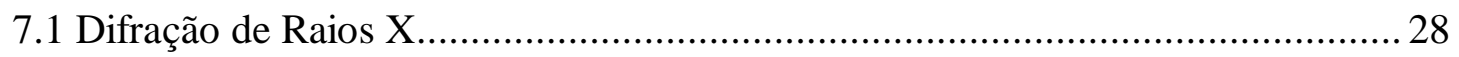

7.2 Microscopia electrônica de Varredura (MEV) ................................................. 29

7.3 Análises químicas de carbono orgânico total (COT) ........................................ 29

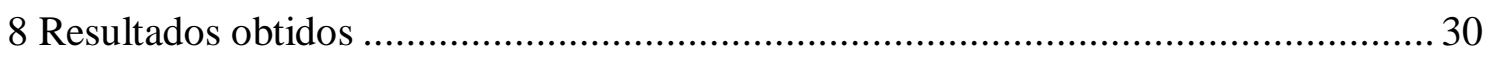

8.1 Caracterização litológica dos afloramentos estudados ...................................... 30

8.2 Microscopia electrônica de Varredura (MEV) e raios X (DRX) ......................... 35

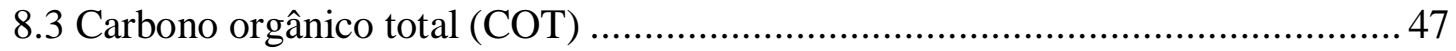

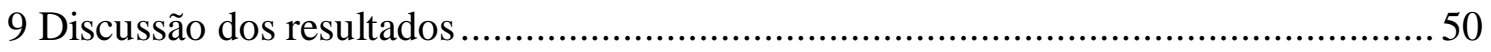

9.1 Composição mineralógica das rochas........................................................... 50

9.2 Avaliação da distribuição de COT ……..................................................... 51

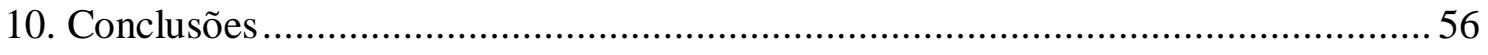

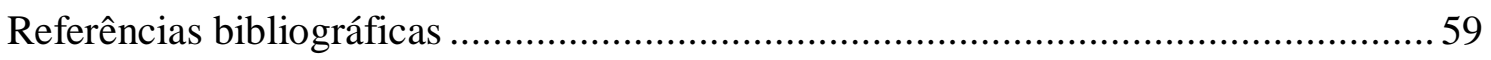

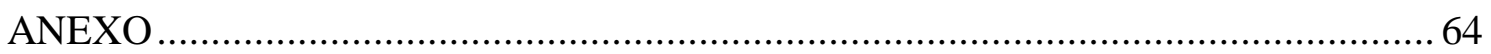




\section{ÍNDICE DE FIGURAS}

Figura 1. Mapa de localização das sinéclises intracratônicas paleozoicas brasileiras.... 13

Figura 2. Divisão da Província Sedimentar do Meio Norte. ......................................... 14

Figura 3. Carta estratigráfica da Bacia do Parnaíba...................................................... 16

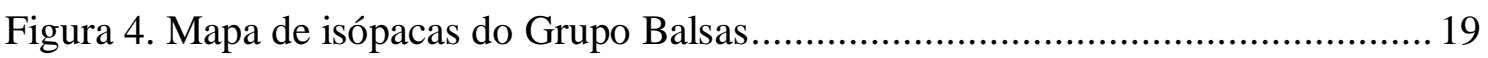

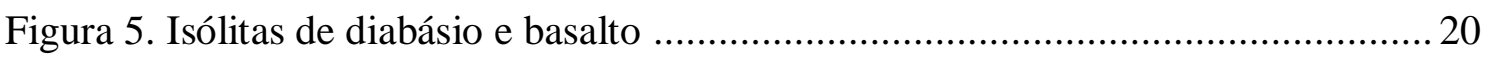

Figura 6. Rochas ígneas mesozoicas na Provincia Parnaíba.................................... 22

Figura 7. Seção geologica esquematíca da Bacia do Parnaíba .................................... 23

Figura 8. Principais lineamentos das províncias Parnaíba e Borborema. .................... 24

Figura 9. Principais lineamentos e feições estruturais do Ciclo Brasiliano ................... 25

Figura 10. Mapa de isópacas e isolítas da Provincia de Parnaíba).............................. 26

Figura 11. Localização dos afloramentos estudados na Bacia do Parnaíba.................. 31

Figura 12. Folhelhos e arenitos da Formación Longá............................................... 32

Figura 13. Folhelhos intercalados com arenitos, Formação Longá. .............................. 33

Figura 14. Folhelhos da Formação Longá, Estação LTB-223....................................... 33

Figura 15. Folhelho cinza da Formacão Pimenteiras, Estação LTB-211 ...................... 34

Figura 16. Detalhe dos folhelhos cinza da Formacão Pimenteiras, Estação LTB-211 ... 34

Figura 17. Difratogramas de raios X obtidos para amostras totais da Formação Longá..

Figura 18. Espectro de EDS e imagem de MEV (SE) ............................................ 38

Figura 19. (A) Imagem de MEV (SE). (B) Imagem de MEV (SE) ............................ 39

Figura 20. Difratogramas de raios X obtidos para amostra total da Formação Longá, aflorantes na borda oeste da Bacia do Parnaíba.............................................................. 40

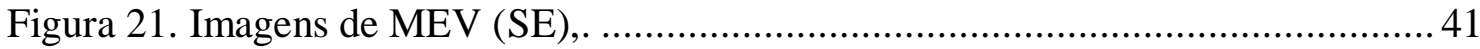

Figura 22. Imagem de detalhe de MEV (SE) com os pontos marcados para EDS ........43

Figura 23. Difratogramas de raios $\mathrm{X}$ obtidos para amostras totais da Formação Pimenteiras, aflorantes na borda oeste da Bacia do Parnaíba. ..................................... 44

Figura 24. Imagem de MEV (SE) mostrando os planos de estratificação do folhelho da Formação Pimenteiras (amostra LTB211) ............................................................. 45

Figura 25. Imagem de detalhe de MEV (SE) mostrando a presença de pirita .............. 45

Figura 26. (A) Imagem de MEV (SE), mostrando a matriz da amostra LTB-211 „....... 46 Figura 27. Difratograma de raios X obtido para amostra total da Formação Tianguá, aflorante na borda leste da Bacia do Parnaíba. 
Figura 28. Distribução espacial dos valores de COT (em \%) nas amostras da Formação

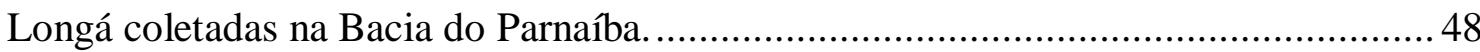

Figura 29. Esquema simplificado das intrusões de rochas magmáticas nos folhelhos da

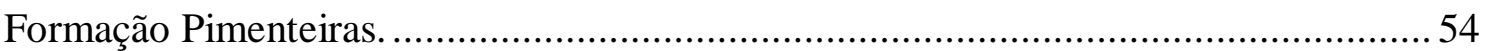

Figura 30. Paleogeografia do Gondwana no intervalo Mesodevoniano a Eeocarbonífero. 55 


\section{Introdução}

A Formação Longá integra a sucessão devoniana da Bacia do Parnaíba, uma sinéclise intracratônica com cerca de $670.000 \mathrm{~km}^{2}$ de área localizada nas regiões nordeste e norte do Brasil. De idade paleozoica, a Bacia do Parnaíba apresenta longa historia evolutiva, marcada por discordâncias expressivas e com uma pilha sedimentar que alcança $3.500 \mathrm{~m}$ na porção mais profunda da bacia (Vaz et al. 2007), o que lança dúvidas quanto à suficiência e eficiência do soterramento para a geração de hidrocarbonetos.

A Formação Longá encerra folhelhos cinza-escuro laminados e siltitos bioturbados, com arenitos amarelados a esbranquiçados argilosos (Santos \& Carvalho 2004), que atingem espessura da ordem de $220 \mathrm{~m}$ em sondagem (Vaz et al. 2007). Os poucos dados disponíveis sobre as concentrações de carbono orgânico total (COT) para os folhelhos da Formação Longá mostram valores inferiores a 1\% (Rodrigues 1995), o que, comparado com os folhelhos da Formação Pimenteiras, parte da mesma sucessão devoniana, com concentrações médias de COT entre 2,0 e 2,5\% e picos de até $6 \%$ (Lobato \& Borghi 2007), os tornaram menos atraentes com vistas a estudos sobre seu potencial gerador.

A principal faixa de afloramentos da Formação Longá ocorre na parte leste da Bacia do Parnaíba, quase que integralmente no Estado do Piauí, com uma pequena porção no Ceará. Ocorre também ao longo da borda oeste da bacia, no Estado do Tocantins. A porção norte da faixa oriental e a porção sul da faixa ocidental de afloramentos são seccionadas pelo Lineamento Transbrasiliano, uma extensa zona de cisalhamento com atividade tectônica recorrente durante o Neoproterozoico e o Fanerozoico, e que apresenta registros de movimentação (falhas sinsedimentares e sismitos) penecontemporânea à deposição da Formação Longá na parte oeste da bacia, no Estado de Tocantins (Chamani 2011). Além disso, na faixa principal de afloramentos da Formação Longá ocorrem rochas vulcânicas básicas intrusivas e extrusivas de idades eotriássica e eocretácea, que representam um aspecto importante na evolução térmica da bacia (Vaz et al. 2007). Segundo Góes \& Feijó (1994), os efeitos térmicos devido ao calor gerado pelas intrusões, somados aos efeitos naturais de soterramento, causaram a maturação dos principais níveis geradores da Bacia do Parnaíba e seriam responsáveis pelo acréscimo de calor necessário à maturação da matéria orgânica (Rodrigues 1995, Alves \& Rodrigues 1985). 
Entretanto, pouco se conhece sobre a distribuição do carbono orgânico total na Formação Longá, nem tampouco se esta distribuição apresenta relações com a sedimentação, bem como o tectonismo e magmatismo aos quais a unidade esteve sujeita. Dados de sondagens são escassos e restritos a relatórios internos da Petrobrás. Programa de sondagem foi também conduzido pela Companhia de Pesquisa de Recursos Minerais (CPRM), com foco em possíveis ocorrências de carvão situadas estratigraficamente acima da Formação Longá.

\section{Objetivos}

De modo a se obter um quadro geral da distribuição do conteúdo de carbono orgânico total (COT) em folhelhos da Formação Longá, recorreu-se ao estudo de afloramentos selecionados desta formação situados ao longo das bordas leste e oeste da Bacia do Parnaíba, tendo em vista os seguintes objetivos:

- amostrar folhelhos da Formação Longá, procurando-se rochas tão sãs quanto o possível, para a realização de análises para determinação dos teores de COT e estudos mineralógicos;

- obter um quadro geral da composição mineralógica dos folhelhos da Formação Longá e suas possíveis variações em área;

- avaliar se a distribuição dos valores de COT na Formação Longá reflete o controle deposicional e/ou se os efeitos da atividade tectônica (no caso o Lineamento Transbrasiliano) e magmática (resultante do efeito térmico do magmatismo do Triássico e Cretáceo atuantes na Bacia do Parnaíba) influenciaram na distribuição da matéria orgânica;

- comparar os resultados obtidos para a Formação Longá com os dados disponíveis para os folhelhos da Formação Pimenteiras. 


\section{Contexto geológico}

\subsection{Estratigrafia da Bacia do Parnaíba}

A Bacia do Parnaíba ocupa uma área de $670.000 \mathrm{~km}^{2}$ da região nordeste e norte do Brasil. Distribui-se pelos estados do Piauí, Maranhão, Tocantins, Pará, Ceará e Bahia (Figura 1). A bacia representa a porção remanescente de uma extensa área de sedimentação que cobria originalmente o nordeste brasileiro e provavelmente parte da África ocidental.

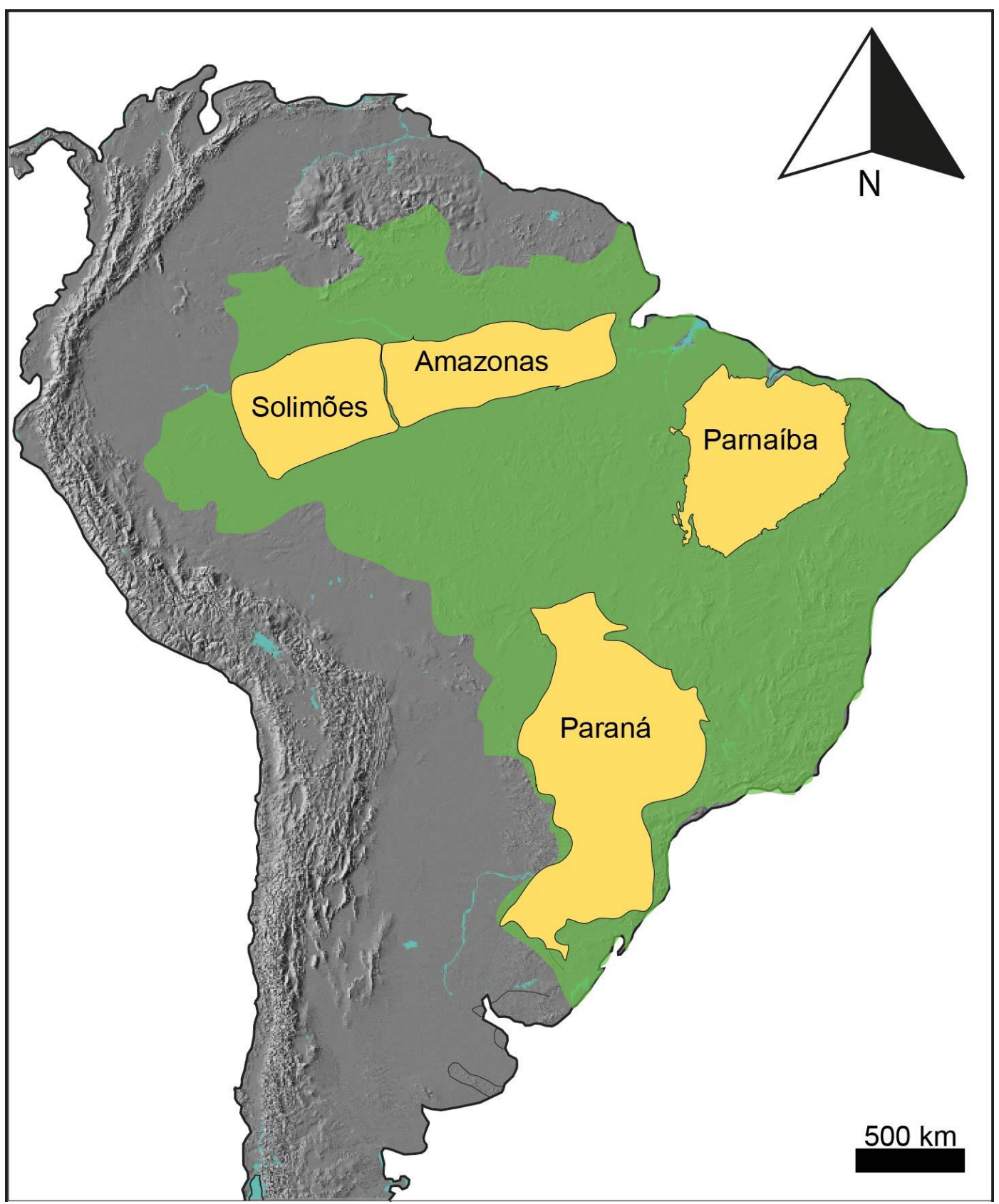

Figura 1. Mapa de localização das sinéclises intracratônicas paleozoicas brasileiras. 
O registro sedimentar da Bacia do Parnaíba compreende três grandes ciclos transgressivo-regressivos, que ocorreram desde o Siluriano, até a continentalização da bacia no Triássico (Góes 1995). Goés \& Feijó (1994) atribuíram a designação de Província Sedimentar de Meio Norte ao conjunto de rochas paleozoicas, mesozoicas e cenozoicas em diferentes bacias com gênese e idades distintas. Góes (1995) reconheceu na área da Província Sedimentar do Meio Norte a existência de quatro bacias superimpostas, denominadas de Bacia do Parnaiba (Siluriano-Triássico), Bacia Alpercatas (Jurássico - Eocretáceo), Bacia do Grajáu (Cretáceo) e Espigão Mestre (Cretáceo) (Figura 2).

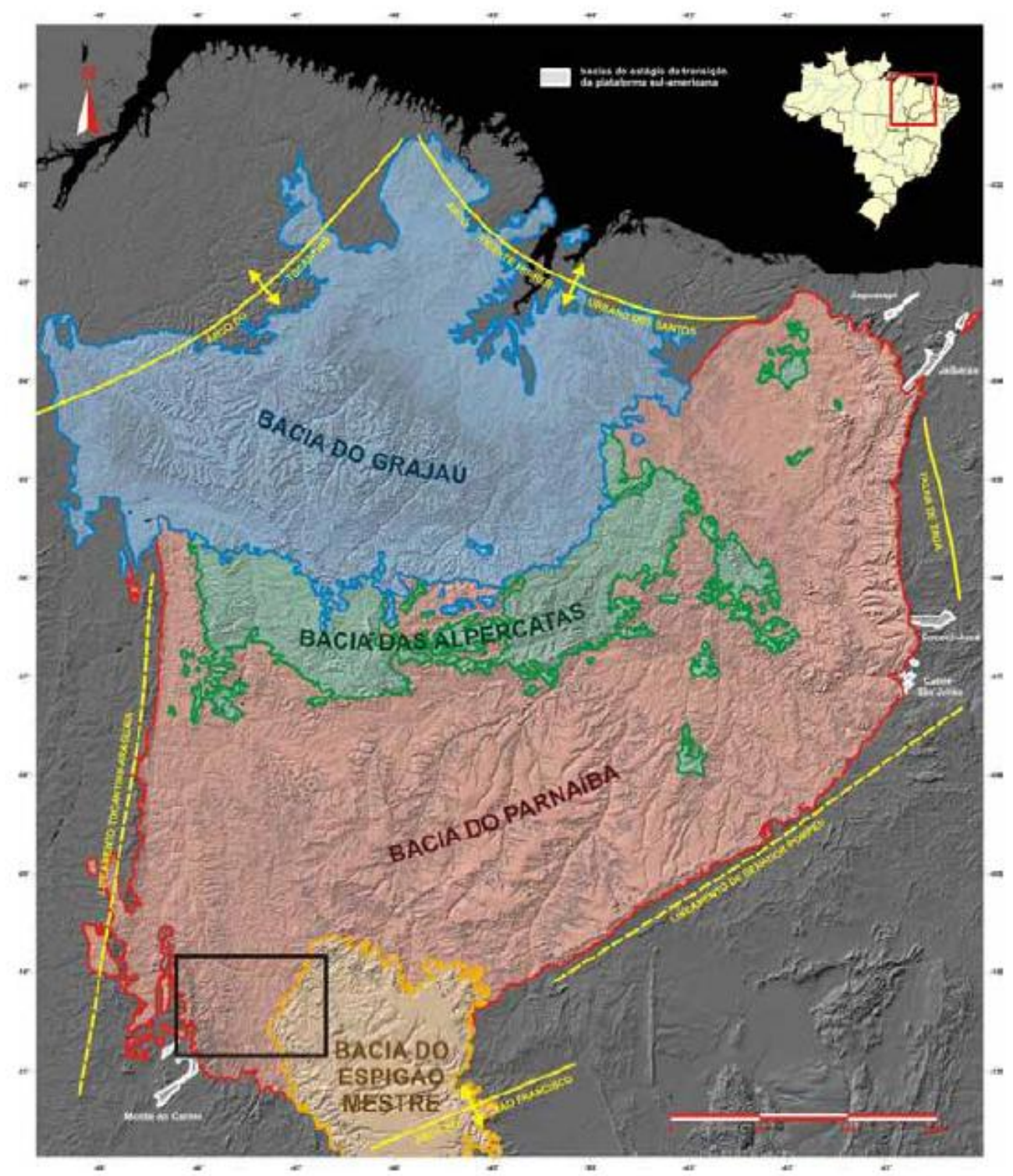

Figura 2. Divisão da Província Sedimentar do Meio Norte, mostrando os quatro sítios deposicionais distintos e as principais estruturas que a limitam a compartimentação tectônica proposta por Goés (1995) (Segundo Chamani 2011). 
A Bacia do Parnaíba compreende rochas paleozoicas correspondentes aos grupos Serra Grande, Canindé e Balsas (Góes \& Feijó 1994).

As mais extensas transgressões marinhas do Fanerozóico da América do Sul estão registradas no Devoniano. Estruturas sedimentares presentes em pelitos depositados em mares batidos por tempestades, juntamente com os fósseis marinhos paleozoicos (Sepkoski, 1990) são indicativos dessas transgressões na bacia. Para Vaz et al. (2007), movimentos eustáticos do nível do mar são os principais responsáveis pelas discordâncias entre as sequências, uma vez que a eustasia controla os ciclos transgressivo-regressivos. A proposta estratigráfica destes autores sugere uma relação de cinco supersequências deposicionais que seguem do período Siluriano até o Cretáceo (Figura 3). 


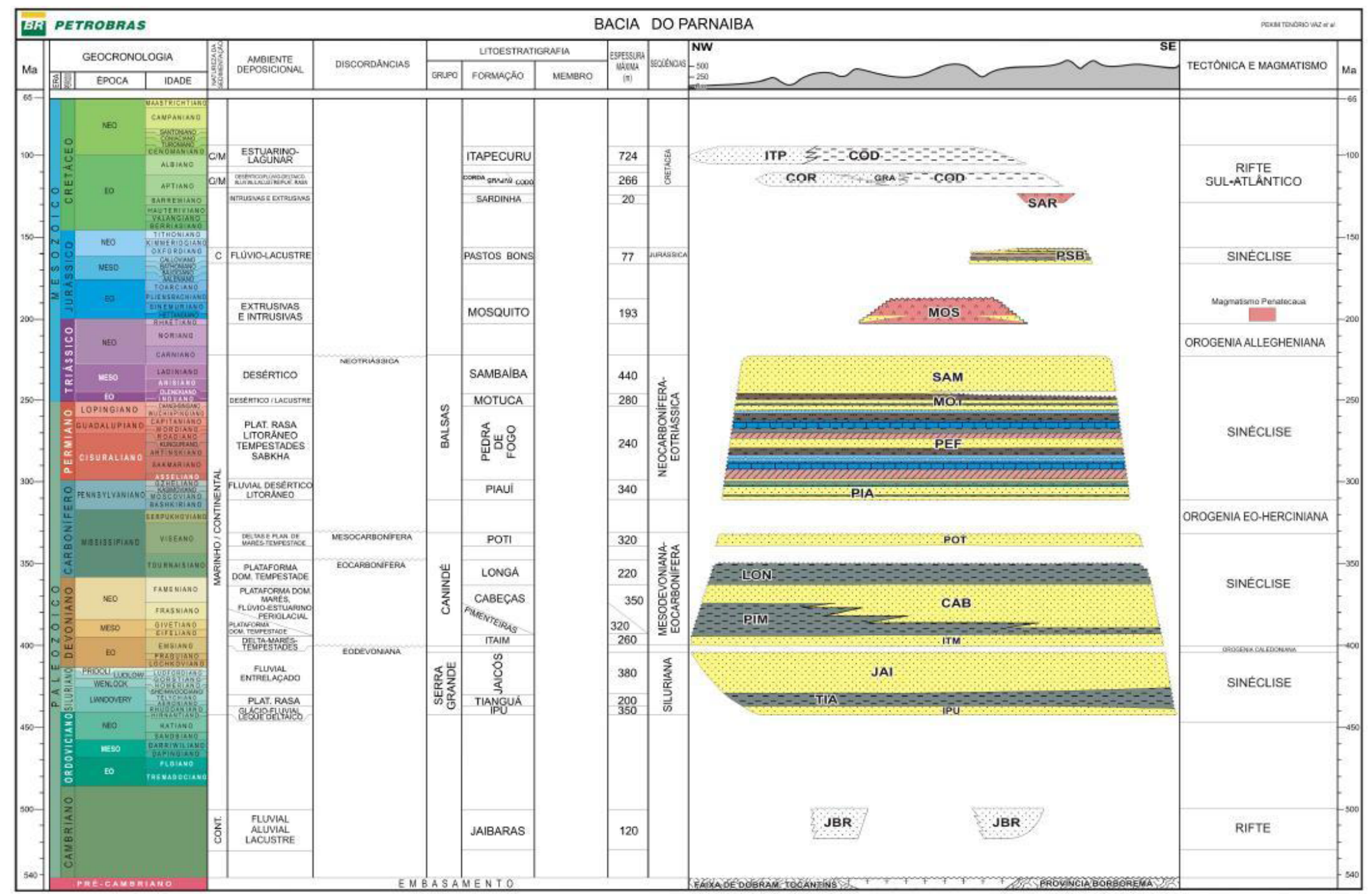

Figura 3. Carta estratigráfica da Bacia do Parnaíba (Vaz et al. 2007). 
O Grupo Serra Grande corresponde à sequência siluriana, um ciclo transgressivo-regressivo completo, depositado sobre rochas proterozoicas. Este grupo é dividido nas formações Ipu, Tianguá e Jaicós (Caputo \& Lima 1984). A Formação Ipu é composta por arenitos com seixos e conglomerados com matriz argilosa, que caracterizam grande variedade de ambientes deposicionais, de glacial a fluvial e leques deltaicos (Caputo \& Lima 1984). A Formação Tianguá compreende folhelhos cinza escuros com arenitos intercalados e bioturbados depositados em ambiente de plataforma rasa (Góes et al. 1990). A Formação Jaicós é composta de arenitos e conglomerados mal selecionados, com pelitos subordinados, ora interpretadas como depósitos fluviais (Kegel 1953, Beurlen 1965), ora de plataforma rasa (Bigarella 1973, Mabesoone 1978), de frente deltaica (Carozzi et al. 1975) ou ainda de leques aluviais e frentes deltaicas (Caputo \& Lima 1984). Segundo Góes et al. (1990) o término da sedimentação do Grupo Serra Grande é marcado pela Orogenia Caledoniana, ou seja, o intervalo regressivo representado por esta unidade.

O Grupo Canindé encerra as formações Itaim, Pimenteiras, Cabeças, Longá e Poti. A Formação Itaim é constituída por arenitos finos a médios esbranquiçados, com intercalações de folhelhos bioturbados, depositados em ambientes deltaicos e plataformais com correntes de marés e tempestades. A Formação Pimenteiras é composta por folhelhos escuros ricos em matéria orgânica (Vaz et al. 2007). O ambiente de deposição foi interpretado como marinho de plataforma com o registro da maior transgressão marinha com oscilações do nível do mar que ocorreu no Devoniano (Caputo 1984, Vaz et al, 2007). Esta formação se destaca na Bacia do Parnaíba por ser o principal alvo exploratório para hidrocarbonetos. Na Formação Cabeças predominam os arenitos depositados em ambiente plataformal sob influência de correntes decorrentes de processos de marés. Esses arenitos são considerados reservatórios potenciais da Bacia do Parnaíba. A Formação Longá, primeiramente descrita por Alburquerque \& Dequech (1946), é composta de folhelhos cinza escuros, por vezes laminados e bioturbados, arenitos esbranquiçados finos e argilosos, de ambiente plataformal dominado por tempestades (Góes \& Feijó 1994). A Formação Poti é composta por arenitos esbranquiçados, com lâminas de siltito subordinadas, com ocorrências de alguns níveis de silexito (Shobbenhaus et al. 1984) associados a deltas e planícies de maré sob influencia ocasional de tempestades. Os trabalhos que discutem os ambientes deposicionais desta formação consideram seus depósitos inferiores como sendo de 
origem continental. Entretanto, desde Lima Filho (1991), Ribeiro \& Melo (1996) e Lima Filho et al. (1998) são descritos também depósitos costeiros na borda leste da bacia. O encerramento do ciclo deposicional do Grupo Canindé é marcado por uma notável discordância regional associada por Góes et al. (1990), Góes \& Feijó, (1994) e Vaz et al. (2007) à Orogenia Eoherciniana.

O Grupo Balsas compreende as formações Piauí, Pedra de Fogo, Motuca e Sambaíba. Na Formação Piauí predominam arenitos intercalados com folhelhos. Góes \& Feijó (1994) atribuem a deposição a um ambiente continental e litorâneo, sob clima extremamente árido. A Formação Pedra do Fogo é caracterizada por uma grande variedade de rochas, com presença de sílexito intercalado com arenito fino a médio, folhelho, siltito, e por vezes dolomito, e excepcionalmente anidrita. As rochas desta formação são associadas por Góes \& Feijó (1994) a um ambiente marinho raso a litorâneo, com planícies de sabkha. A Formação Motuca é composta predominantemente por arenitos e siltitos com intercalações de calcários e leitos de gipsita (Shobbenhaus et al. 1984). Ocorrem subordinadamente anidrita e raros calcários depositados em um sistema desértico controlado por sistemas lacustres (Goés \& Feijó 1984). Na Formação Sambaíba predominam arenitos bem selecionados associados a um sistema eólico em ambiente desértico (Góes \& Feijó 1994). Essa sucessão marca mudanças ambientais e tectônicas profundas na região, que levaram à mudança dos eixos deposicionais com direção NE-NW para o centro da bacia (Figura 4) e restringiram a circulação dos mares abertos (Góes et al. 1990). Segundo tais autores essa sequência também compõe um ciclo transgressivo-regressivo, porém sob condições marinhas rasas e restritas, em clima quente e árido, propiciando a deposição de evaporitos e a desertificação progressiva da área. 


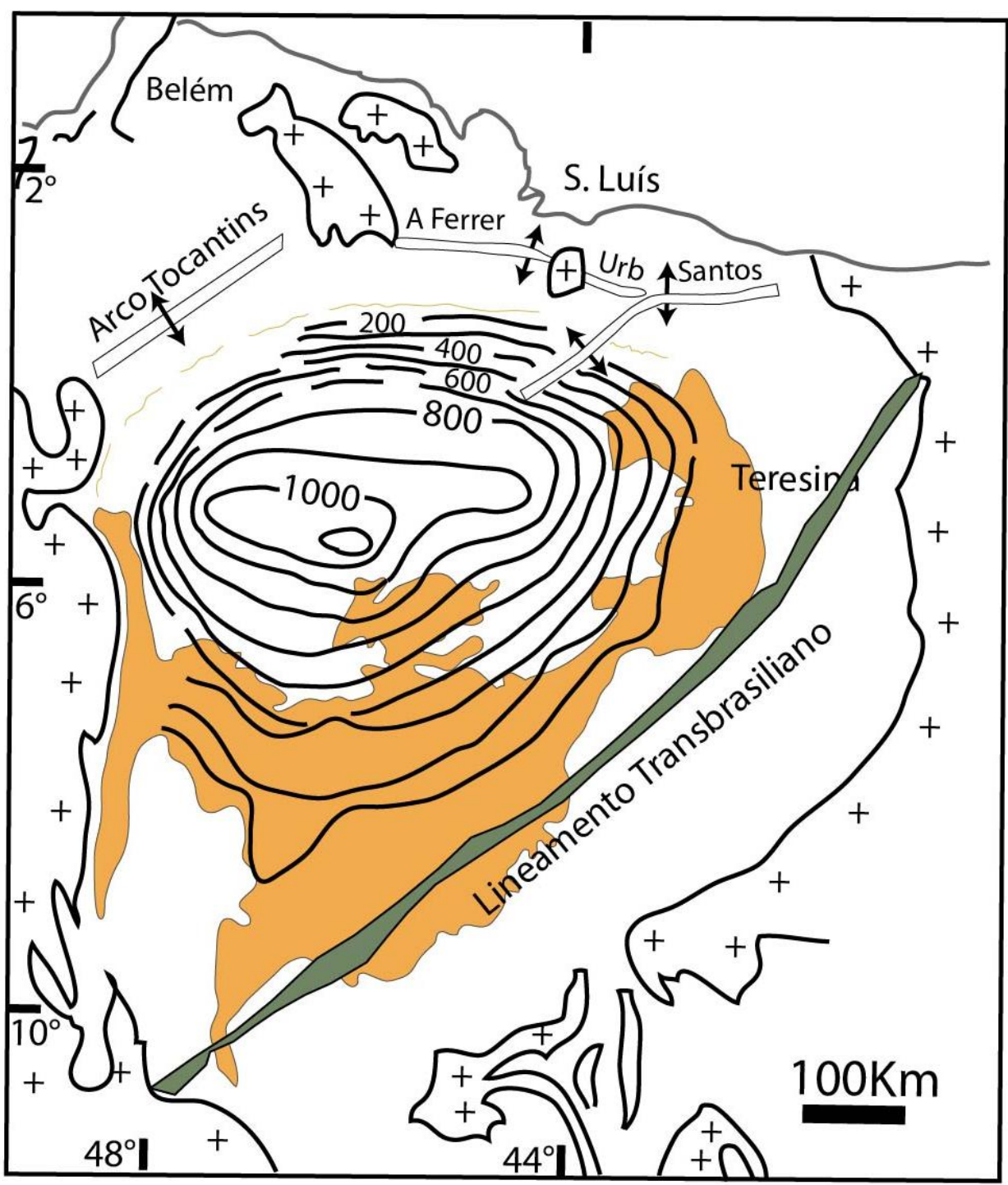

Figura 4. Mapa de isópacas do Grupo Balsas (Segundo Góes et al. 1993).

A Formação Pastos Bons, composta por arenitos nas porções basal e superior e siltitos e folhelhos por vezes intercalados com arenito na porção intermediária (Vaz et al. 2007), é relacionada a uma quarta sequência, de idade jurássica. A deposição dessa sequência seria relacionada à subsidência causada pela soma dos pesos da carga de derrames basálticos e da carga sedimentar existente (Figura 5, Góes et al. 1993). O fim dessa fase sedimentar seria consequência de processos tectônicos associados à abertura do Atlântico Equatorial (Vaz et al. 2007). 

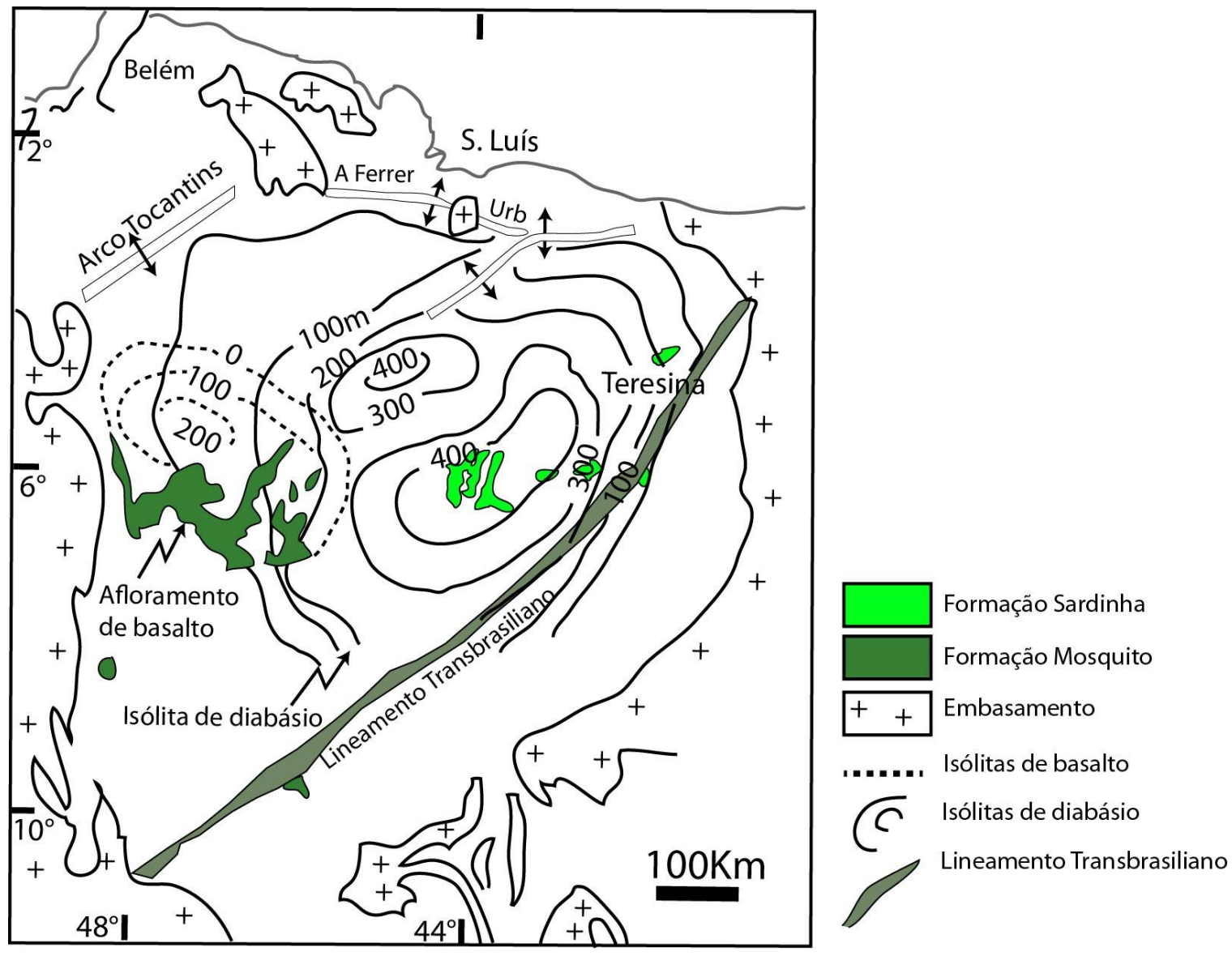

Figura 5. Isólitas de diabásio e basalto mostrando a distribuição da Formação Mosquito e Sardinha as quais encontram-se intrudindo principalmente rochas paleozoicas.

(Segundo Góes et al. 1993).

A sucessão sedimentar cretácea é composta pelas formações Codó, Corda, Grajaú e Itapecuru, depositadas na Bacia do Grajaú (Rossetti \& Góes, 2001). A Formação Corda é composta essencialmente por arenitos com estratificação cruzada de grande porte que sugerem a deposição em sistema desértico (Vaz et al. 2007). Na Formação Grajaú predominam arenitos esbranquiçados, finos a conglomeráticos. A Formação Codó é composta por folhelhos, calcários, siltitos, gipsita/anidrita e por arenito com níveis de sílex e estromatólitos. A Formação Itapecuru compreende predominantemente arenitos e subordinadamente pelitos e arenitos conglomeráticos.

A tectônica que atuou na abertura do Atlântico Equatorial refletiu na estrutura interna da Bacia do Parnaíba e suas sucessoras durante o Cretáceo, acarretando o deslocamento dos depocentros, que se mantinham até então na região central, para norte e nordeste (Vaz et al. 2007). 


\subsection{Formação Longá}

A designação Formação Longá foi proposta por Albuquerque \& Dequech (1946) para o pacote de folhelhos cinza-escuros que ocorre no Vale do Rio Longá, próximo a Campo Maior, no Piauí. Posteriormente foi dividida em três subunidades: uma arenosa, média e duas pelíticas, inferior e superior. Os folhelhos da Formação Longá sobrepõemse aos arenitos da Formação Cabeças, acentuando uma mudança litológica abrupta. A parte média da formação é marcada por arenitos amarelados a esbranquiçados, argiláceos com estratificações cruzadas e delgados leitos de calcários argilosos. O contato superior, com a Formação Poti, em geral é concordante e gradacional, embora possa ser localmente brusco (Della Fávera 1990). Os depósitos da Formação Longá são interpretados como o registro de um mar epicontinental, com ambiente deposicional variando de infranerítico nas unidades basais e superiores, a litorâneo nas seções médias. Os sedimentos com a predominância de clásticos finos da unidade inferior refletem um rápido afogamento do sistema marinho raso da Formação Cabeças pela elevação do nível do mar, no final de uma glaciação. Os folhelhos laminados com estratificação cruzada hummocky indicam uma sedimentação mais profunda, com tempestades (Della Fávera 1990).

\subsection{Rochas ígneas mesozoicas}

$\mathrm{Na}$ Bacia do Parnaíba ocorrem rochas ígneas intrusivas (diques e soleiras) e extrusivas de composição básica, que estratigraficamente foram divididas em duas unidades: Formação Sardinha e Formação Mosquito (Vaz et al. 2007). Estes autores atribuem uma idade média de 124 Ma (Eocretáceo), para a Formação Sardinha e de 178 Ma (Eojurássico) para a Formação Mosquito. Essas unidades diferem também com relação à forma de ocorrência em superfície e distribuição na bacia, sendo que a Formação Sardinha ocorre como grandes diques e pequenas soleiras nas porções centroleste e nordeste, e a Formação Mosquito em grandes derrames e pequenas soleiras na porção centro-oeste e, mais restritamente, sul da bacia (Vaz et al. 2007, Figura 6). 


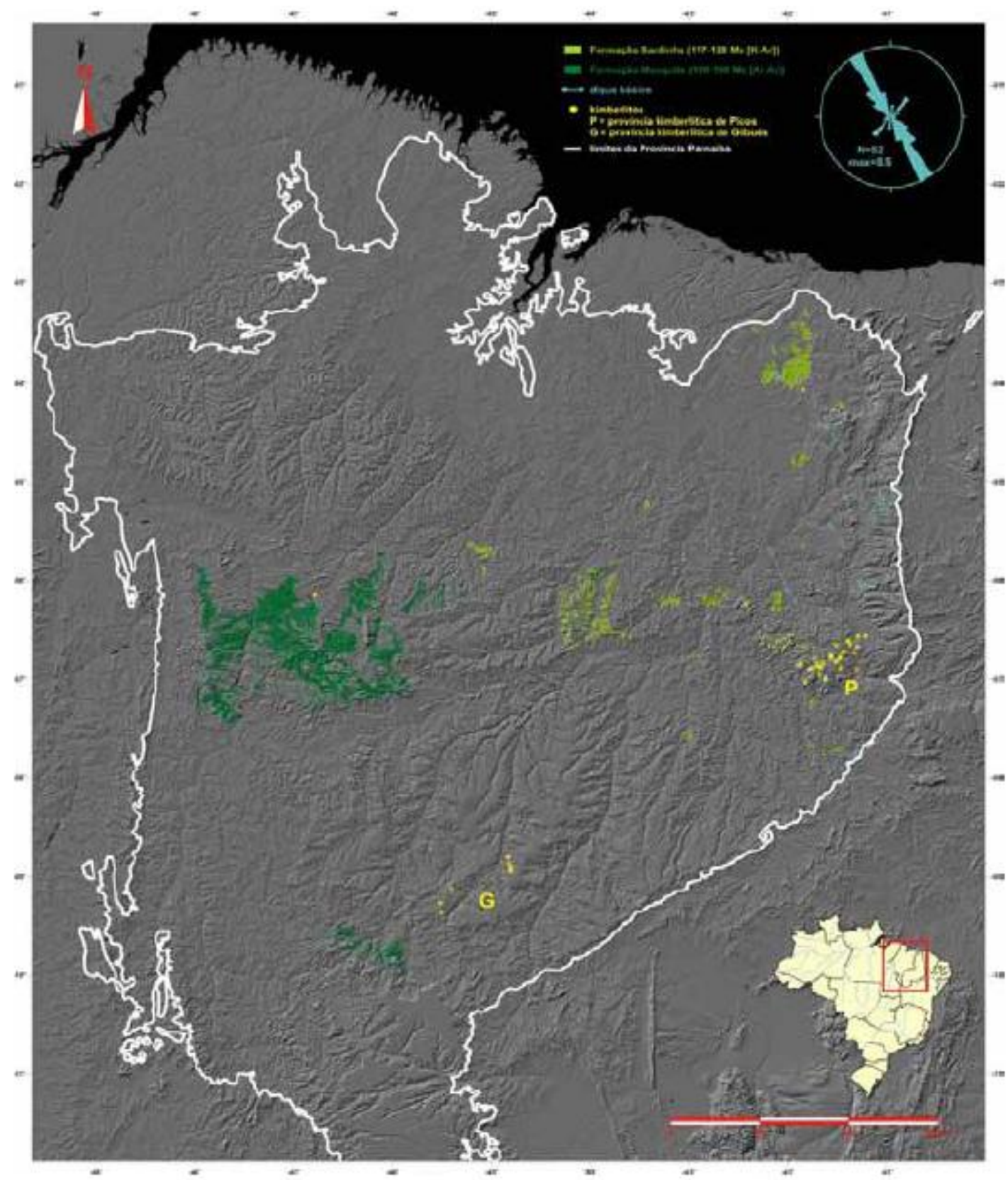

Figura 6. Rochas ígneas mesozoicas na Provincia Parnaíba. Área de ocorrência das formações Sardinha (verde claro) e Mosquito (verde escuro) (Segundo Chamani 2011).

A partir de interpretação sísmica, Vaz et al. (2007) verificaram soleiras em uma grande extensão da Bacia do Parnaíba, sem no entanto diferenciá-las como Formação Mosquito ou Sardinha. Mizusaki \& Thomas Filho (2004) sugerem que as manifestações magmáticas com idade em torno de 130 Ma podem estar relacionadas com o processo de rifteamento e consequente formação do Oceano Atlântico Sul. Dentro de um contexto evolutivo de distensão crustal, o rift precursor do Atlântico Sul teria se propagado de SW para NE induzindo as manifestações magmáticas que hoje podem ser 
reconhecidas na Bacia do Parnaíba (Mizusaki \& Thomas Filho 2004). Essas manifestações seriam referentes às rochas ígneas da Formação Sardinha. Já o magmatismo que originou a Formação Mosquito estaria relacionado ao rifteamento e posterior abertura do Atlântico Central (Marzoli et al. 1999).

\section{Arcabouço estrutural}

A Bacia do Parnaíba é classificada como intracratônica, possui forma grosseiramente circular e depocentro levemente elíptico com orientação NW-SE. Desenvolvida sobre um embasamento continental durante a fase de estabilização da Plataforma Sul- Americana (Almeida \& Carneiro 2004), sua instalação tem sido vinculada à estrutura preexistente relacionada aos pulsos terminais do Ciclo Brasiliano, responsável pela formação de grábens por toda a área subjacente à bacia, com eixos orientados de nordeste a norte e que teriam controlado o depocentro inicial da bacia (Cordani et al. 1984, Góes et al. 1990, Vaz et al. 2007, Figura 7).

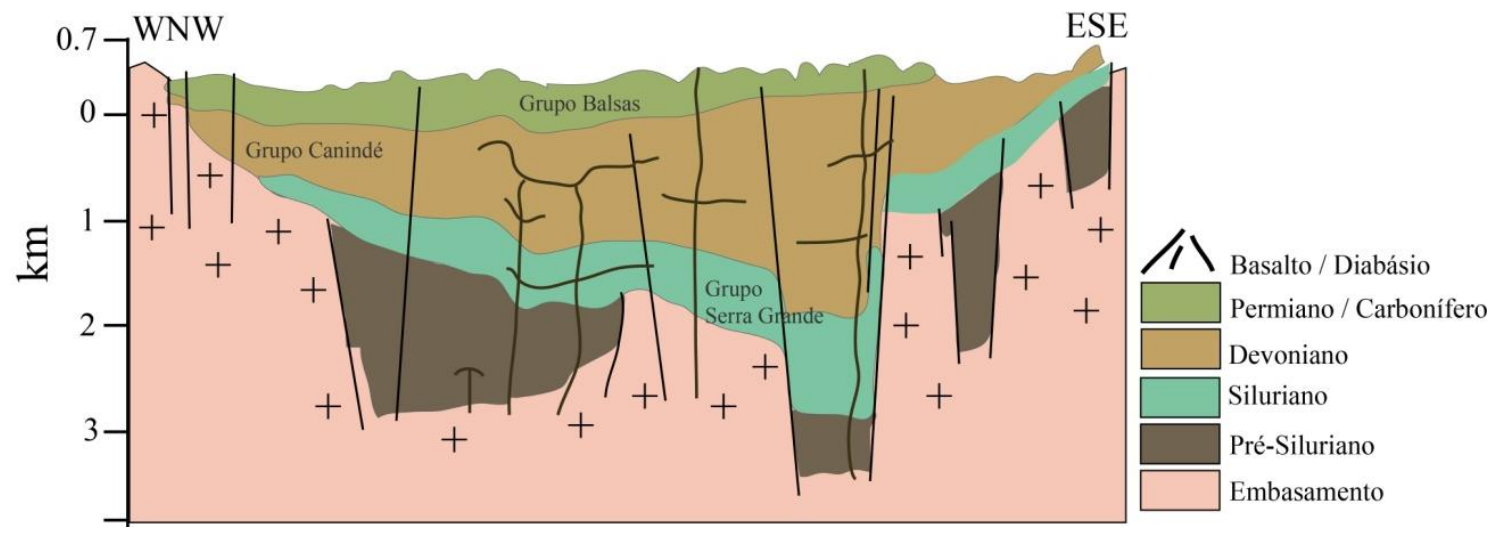

Figura 7. Seção geologica esquematíca da Bacia do Parnaíba (Modificado de Góes et al., 1990).

Esses sítios deposicionais, ou riftes precursores da Bacia do Parnaíba, teriam como equivalentes aflorantes o Graben Jaibaras e outros grabens situados na Província Borborema, que foram gerados em um sistema de riftes do final do Proterozoico e início do Paleozoico (Vaz et al. 2007, Figura 8). 


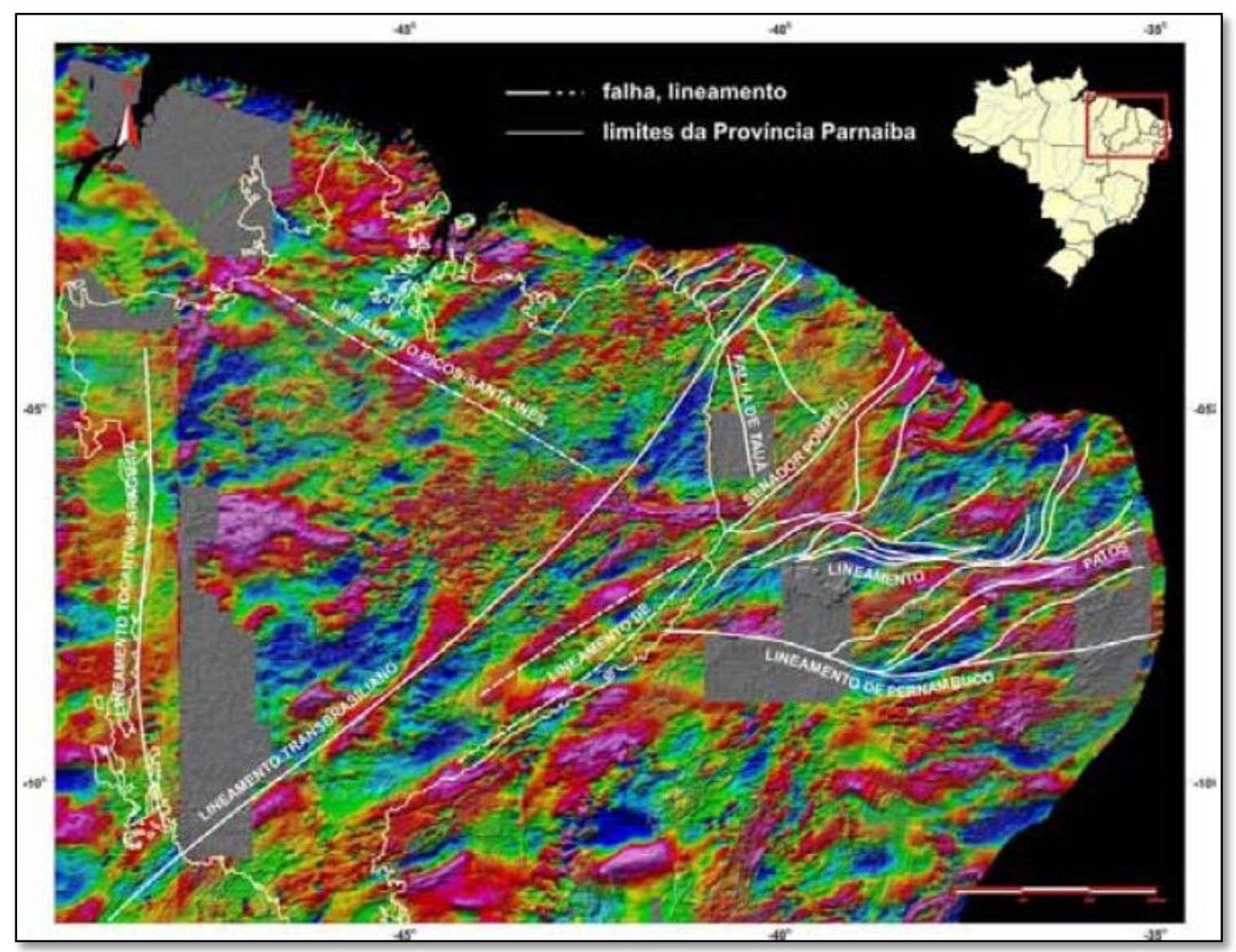

Figura 8. Principais lineamentos das províncias Parnaíba e Borborema. A estrutura mais importante é o Lineamento Transbrasiliano (LTB) e outros lineamentos importantes na evolução da Província Parnaíba são o Picos-Santa Inês e o Tocantins-Araguaia (Segundo Chamani 2011).

\section{O Lineamento Picos-Santa Inês e a Zona do Lineamento Transbrasiliano} constituem fraturas e falhas herdadas do embasamento, com relevante importância desde a fase inicial da bacia e por toda a sua evolução, pois controlaram as direções dos eixos deposicionais até o Eocarbonífero (Vaz et al. 2007). Esses lineamentos destacamse entre as principais feições estruturais da Bacia do Parnaíba (Figura 9). 


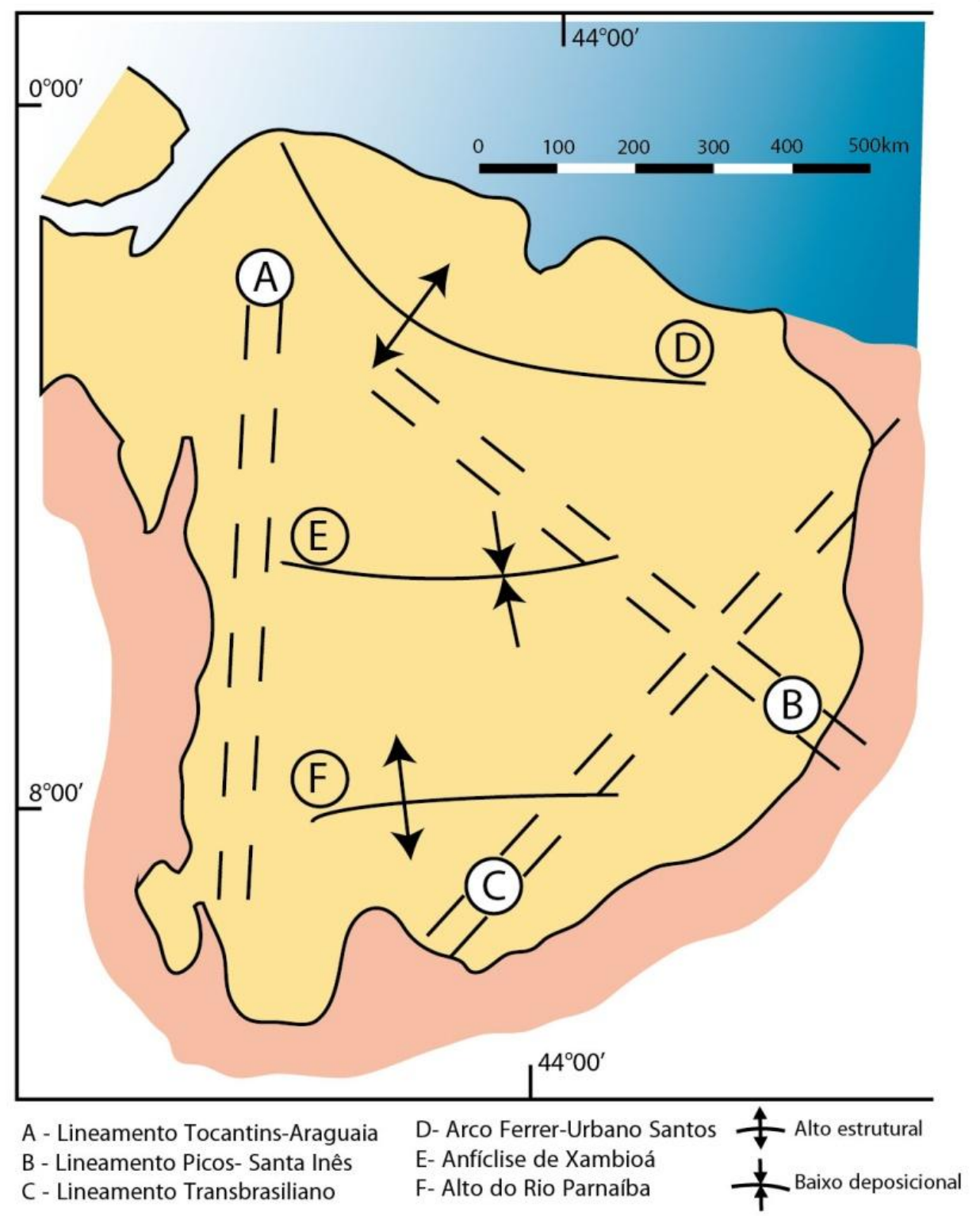

Figura 9. Principais lineamentos e feições estruturais do Ciclo Brasiliano no Paleozoico (A, B , C) e estruturas de compartimentação no Mesozoico (D, E, F) (Santos \& Carvalho 2009).

\section{O Lineamento Transbrasiliano (LTB)}

O lineamento Transbrasiliano é a principal estrutura do embasamento que afeta a região em estudo. O LTB corta seções paleozoicas e mesozoicas e atravessa o território brasileiro de sudoeste para nordeste (Cunha 1986). Abrange um complexo de falhas normais e transcorrentes, altos estruturais e grabens. Delgado et al. (2003) consideram o lineamento ativo a partir do evento colisional Brasiliano II, há cerca de $650 \mathrm{Ma}$. Destro 
et al. (1994) a partir da análise de deformacões em arenitos relacionados ao Grupo Serra Grande no nordeste do Ceará identificaram uma reativação pós-devoniana do LTB. Embora a idade dessas reativações seja ainda incerta, os autores sugeriram uma idade neocretácea por correlação com deformações observadas em outros locais ao longo do LTB.

Mapas de isopácas das unidades litoestratigráficas que compõem o prenchimento da bacia mostram um eixo deposicional fortemente condicionado pelo LTB durante a deposição dos grupos Serra Grande (Siluriano-Devoniano) e Canindé (DevonianoCarbonífero). Durante a deposição do Grupo Balsas (Carbonífero-Triássico) ocorre uma mudança na orientação do eixo de deposição, que assume uma orientação aproximadamente leste-oeste, a mesma mostrada pelas rochas básicas instrusivas e extrusivas (Figura 10).
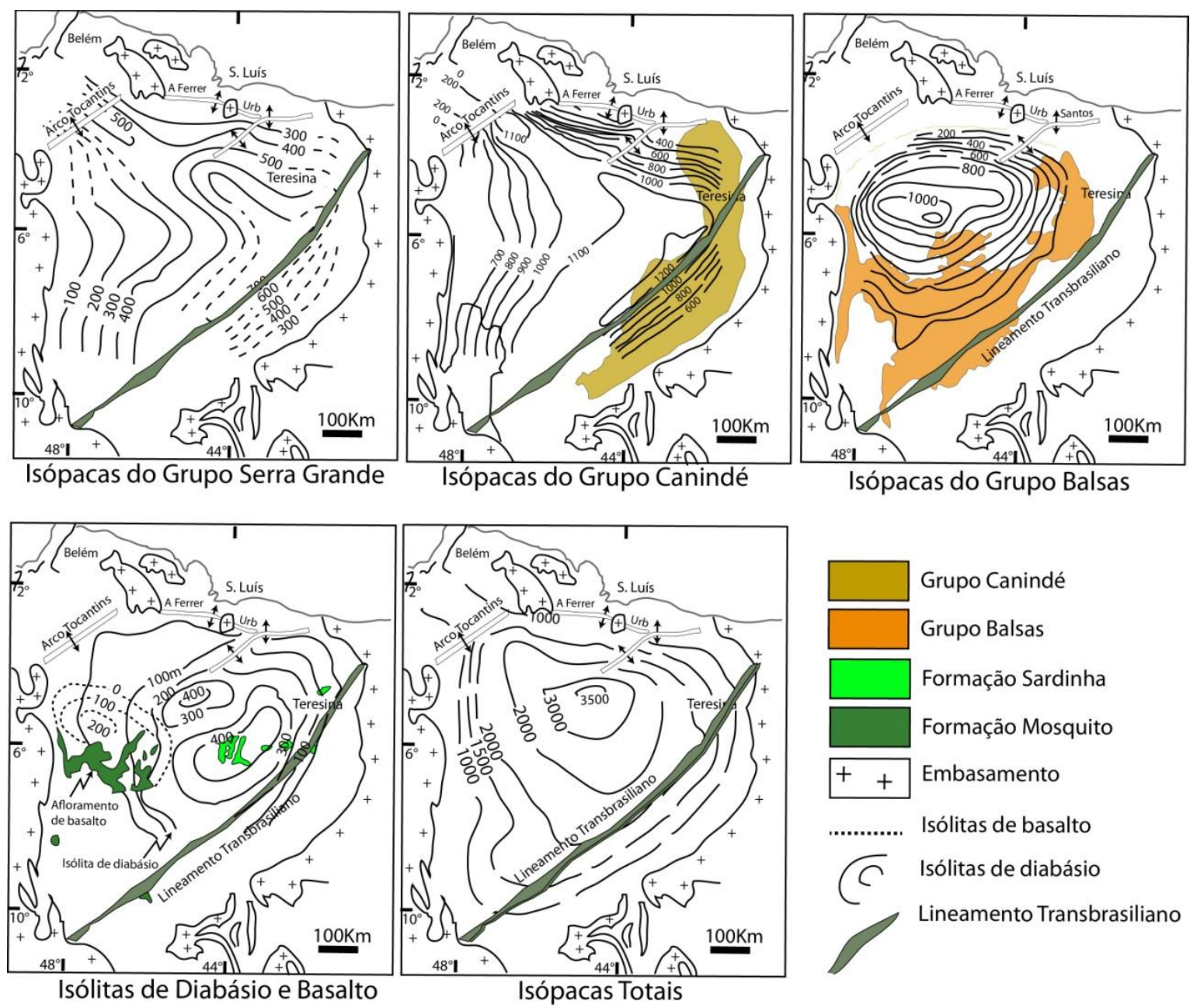

Figura 10. Mapa de isópacas e isolítas da Provincia de Parnaíba (Segundo Goés et al. 1993). 


\section{Tectônica da Bacia do Parnaíba}

A sedimentação paleozoica desenvolveu-se em extensas sinéclises, que tiveram como base uma plataforma consolidada a partir do Ciclo Brasiliano, acompanhada de todos os eventos deformacionais, ígneos, sedimentares e geomorfológicos típicos de orogêneses (Zalán 2004). Um estágio de estabilização, ocorrido do Siluriano ao Jurássico, marcado por calma tectônica e mudança no padrão de sedimentação, foi essencial para o desenvolvimento das sinéclises paleozoicas. As sinéclises passaram a sofrer extensas transgressões e regressões marinhas regionais. Em resposta à subsidência, arcos regionais ergueram-se e circundaram as sinéclises, terminando por separá-las. Entre o Jurássico e o Triássico, sob extrema calma tectônica, toda a plataforma sofreu ascensão, limitando a sedimentação e ocasionando o fim das ingressões marinhas (Zalán 2004).

Na Bacia do Parnaíba, no fim do evento Brasiliano, durante a transição do Cambriano para o Ordoviciano, o resfriamento e a contração da litosfera favoreceram a formação de falhas normais. De acordo com Cunha (1986), estas zonas são bem representadas na Bacia do Parnaíba por expressivos lineamentos, destacando-se o Transbrasiliano e Picos-Santa Inês (Figura 9). As fossas instaladas foram preenchidas por clásticos cambro-ordovicianos, que constituem a estruturação precursora da Bacia do Parnaíba, demarcando no tempo e no espaço o início de sua subsidência (Cunha 1986). Como resultado da evolução termomecânica da área, estabeleceu-se a grande depressão ordoviciana, sobre a qual se depositou a Sequência Siluriana, composta pelos sedimentos flúvio-deltaicos a marinhos rasos do Grupo Serra Grande.

Posteriormente, com o prosseguimento dos processos termais, já com efeitos flexurais, foi depositada a Sequência Mesodevoniana-Eocarbonífera, constituída principalmente pelos sedimentos devonianos do Grupo Canindé (Góes et al. 1990). Do Neocarbonífero até o Jurássico os depocentros deslocaram-se para a parte central da bacia (Góes et al. 1990, Vaz et al. 2007), a sedimentação passou a ter um padrão concêntrico e a forma externa da região deprimida tornou-se ovalada, típica de uma sinéclise interior (Vaz et al. 2007). 


\section{Métodos}

\subsection{Difração de Raios X}

As análises utilizando a difratometria de raios $\mathrm{X}$ (DRX) permitem a identificação de minerais de granulometria fina, com difícil identificação por microscopia óptica. No estudo das amostras totais, a preparação do material incluiu a desagregação e homogeneização das amostras, através de moagem manual em almofariz de ágata, e colocação do material sobre cada porta-amostra pelo método da prensagem do pó (Brindley \& Brown 1980). Este método recebe este nome devido às amostras estarem em forma de um pó microcristalino com uma orientação aleatória dos cristais em relação ao feixe de raios $X$. A técnica da difração de raios $X$ compreende a caracterização dos minerais utilizando os dados do arranjo atômico no reticulo cristalino, com os quais os raios $\mathrm{X}$ podem interagir promovendo as difrações; desse modo, quando todas as espécies cristalinas estão na mistura de pó, cada uma delas registra uma difração diferente (Whitting 1965).

O padrão de difração é feito de uma serie de difratogramas sobrepostos, único para cada fase da amostra (Jenkins \& Snyder 1996). O reconhecimento destas fases pode ser feito utilizando modelos de padrões de fases simples conhecido como arquivo de difração de pó (Powder diffraction file - PDF).

As amostras para as análises por DRX foram preparadas no Laboratório de Caracterização de Rochas de Sistemas Petrolífetos do Instituto de Energia e Ambiente da Universidade de São Paulo. Os difratogramas deste trabalho foram obtidos no Laboratório de Difração de Raios X (LDRX) do Instituto de Geociências da Universidade de São Paulo com o difratômetro Bruker Modelo D8 Advance Da Vinci

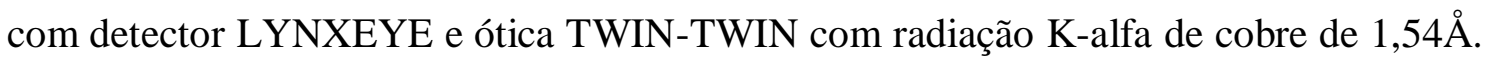
Os difratogramas foram analisados com o software DRXWIN 2.2. (Martin 1999), e os minerais foram identificados com os bancos de dados PDF-2 (ICDD) versão 2009 e COD (Crystallographic Open Database). 


\subsection{Microscopia electrônica de Varredura (MEV)}

A microscopia eletrônica de varredura é utilizada em várias áreas do conhecimento. A imagem eletrônica de varredura é formada pela incidência de um feixe de elétrons no mineral, sob condição de vácuo. A incidência do feixe de elétrons no mineral promove a emissão de elétrons secundários, retroespalhados, além de raios $\mathrm{X}$ caraterísticos (Goldstein \& Newbury 1992). A imagem eletrônica de varredura representa em tons de cinza o mapeamento e a contagem de elétrons secundários (SE: secondary electrons) e retroespalhados (BSE: backscattering electrons) emitidos pelo material analisado.

A imagem de SE fornece detalhes de superfície ionizada do mineral em tons de cinza. Os tons mais claros podem representar as faces do mineral orientadas para o detector, bem como defeitos e bordas dos minerais. A imagem de BSE é gerada pela emissão de elétrons retroespalhados e demonstra diferenças composicionais na região ionizada do mineral. Ao MEV pode ser acoplado o sistema de EDS (Energy Dispersive System), o qual consegue identificar qualitativamente a composição destes minerais, a partir de emissão de raios X característicos (Rouchon et al. 2009).

As imagens apresentadas neste trabalho foram obtidas com o equipamento MEV modelo 440i da marca LEO Electron Microscopy Ltd, do Laboratório de MEV do Instituto de Geociências da Universidade de São Paulo. O equipamento possui um canhão de elétrons com filamento de tungstênio e alto vácuo. As condições analíticas foram: EHT $20 \mathrm{kV}$, corrente de filamento de $25 \mathrm{pA}$ a 1.000 pA e distância de trabalho de $9 \mathrm{~mm}$ a $18 \mathrm{~mm}$.

As microanálises de elementos químicos foram obtidas em espectrômetro por energia dispersiva de raios $\mathrm{X}$ (EDS), que possui um detector de estado sólido do tipo $\mathrm{Si}(\mathrm{Li})$ e é controlado por um software modelo INCA 300 da marca Oxford Instruments Ltd. As condições analíticas foram: tempo de contagem $100 \mathrm{~s}$, tempo de processamento $4 \mathrm{~s}$ e tempo morto de aproximadamente $12 \mathrm{~s}$.

\subsection{Análises químicas de carbono orgânico total (COT)}

O teor de carbono orgânico total (COT) reflete a quantidade de matéria orgânica presente na rocha sedimentar. Esta, por sua vez, é o resultado final da interação entre 
fatores como a quantidade de matéria orgânica disponível para acumulação, a taxa de sedimentação no sítio deposicional e o grau de preservação desta durante a diagênese (Tissot \& Welte 1984). Posteriormente, o valor de COT é influenciado pelo soterramento e as reações responsáveis pela transformação da matéria orgânica em hidrocarbonetos, diminuindo progressivamente ao longo da metagênese e catagênese (Tissot \& Welte 1984).

As preparações das amostras para análise elementar de COT foram feitas no laboratório de tratamento de amostras (LTA) do Instituto de Geociências da USP. O processo consistiu de fragmentação mecânica, pulverização e ataque com ácido clorídrico para eliminação do carbono inorgânico presente, realizados no laboratório de Sedimentologia do IGc-USP. As amostras foram fragmentadas com o uso de prensa hidráulica e a pulverização foi feita no moinho de ágata. Após pesagem, 10g de cada amostra foram atacadas com uma solução de $100 \mathrm{ml}$ de ácido clorídrico a $10 \%$ durante 24h. Após esse prazo, o material foi lavado com água destilada e seco em estufa a uma temperatura de $30^{\circ} \mathrm{C}$ durante $24 \mathrm{~h}$. Este processo permitiu a eliminação do carbono inorgânico, cujo teor foi calculado pela diferença das concentrações de carbono total e carbono orgânico do material depois do ataque, limpeza, filtração e secagem.

Do total do material obtido anteriormente, foi separado $1,5 \mathrm{~g}$ que foi encaminhado à Central Analítica do Instituto de Química da USP para a realização das análises. As análises foram realizadas em um analisador Perkin-Elmer M CHNS/O modelo 2400, com uma margem de erro de $0,3 \%$ e sensibilidade acima de $1 \%$. No total foram feitas 22 análises de amostras de folhelhos das formações Longá (16), Pimenteiras (4), Cabeças (1) e Poti (1).

\section{Resultados obtidos}

\subsection{Caracterização litológica dos afloramentos estudados}

As principais faixas de afloramentos da Formação Longá ocorrem nas partes leste e oeste da Bacia do Parnaíba. As exposições estudadas estão localizadas na porção centro norte da faixa oriental, no Estado do Piauí, e na parte sul da faixa ocidental, em Tocantins. Parte dos afloramentos, em ambas as bordas, encontram-se sob a influência do Lineamento Transbrasiliano. Alguns afloramentos da borda oriental estão situados 
nas proximidades de rochas relacionadas ao magmatismo da Formação Sardinha (Figura 11). No Anexo um estão indicadas as principais informações destes afloramentos.

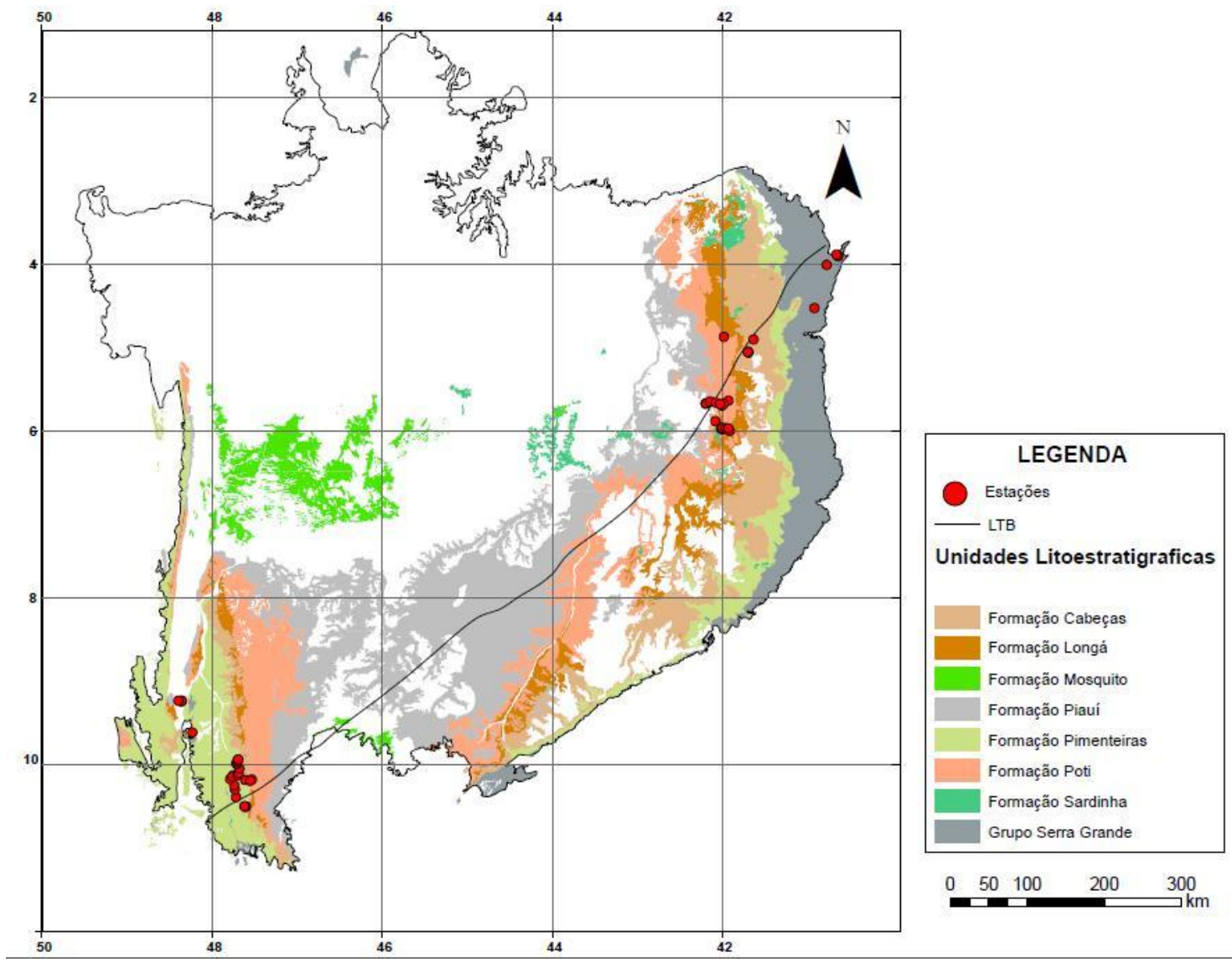

Figura 11. Localização dos afloramentos estudados nas bordas leste e oeste da Bacia do Parnaíba.

Embora as exposições da Formação Longá tenham sido o foco deste trabalho, foram também visitados afloramentos das formações Pimenteiras, Cabeças e Poti. De modo geral, as rochas da Formação Longá compreendem essencialmente folhelhos cinza (claro a escuro) intercaladas com arenitos e subordinadamente siltitos de cor branca, creme, amarela e marrom. Os folhelhos apresentam-se em lâminas (Figura 12 A) e a sua alternância com os arenitos confere ritmicidade na maioria dos casos (Figuras 12 B), localmente com deformações tectônicas (kink band, Figura 13). Ainda nos folhelhos podem ser observados icnofósseis (icnofácies cruziana, Figura $12 \mathrm{C}$ ). Os arenitos intercalados nos folhelhos apresentam laminação plano paralela e cruzada, marcas onduladas de corrente (Figura 12 D) e marcas onduladas com padrão de domos e bacias (Figura 12E), além de icnofósseis (Figura 12 F). Localmente as intercalações de arenito são mais espessas, da ordem de alguns metros (Figura 14). Os afloramentos 
estudados da Formação Pimenteiras, todos situados na borda oeste da bacia, exibem folhelhos cinza em pacotes de espessura métrica (Figura 15). A Formação Cabeças, compreende essencialmente arenitos com finas intercalações de siltitos, e estratificação cruzada. A Formação Poti é composta principalmente por arenitos de cor marrom por vezes esbranquiçado a acinzentado, meio a grosso por vezes conglomeráticos intercalados com siltitos.
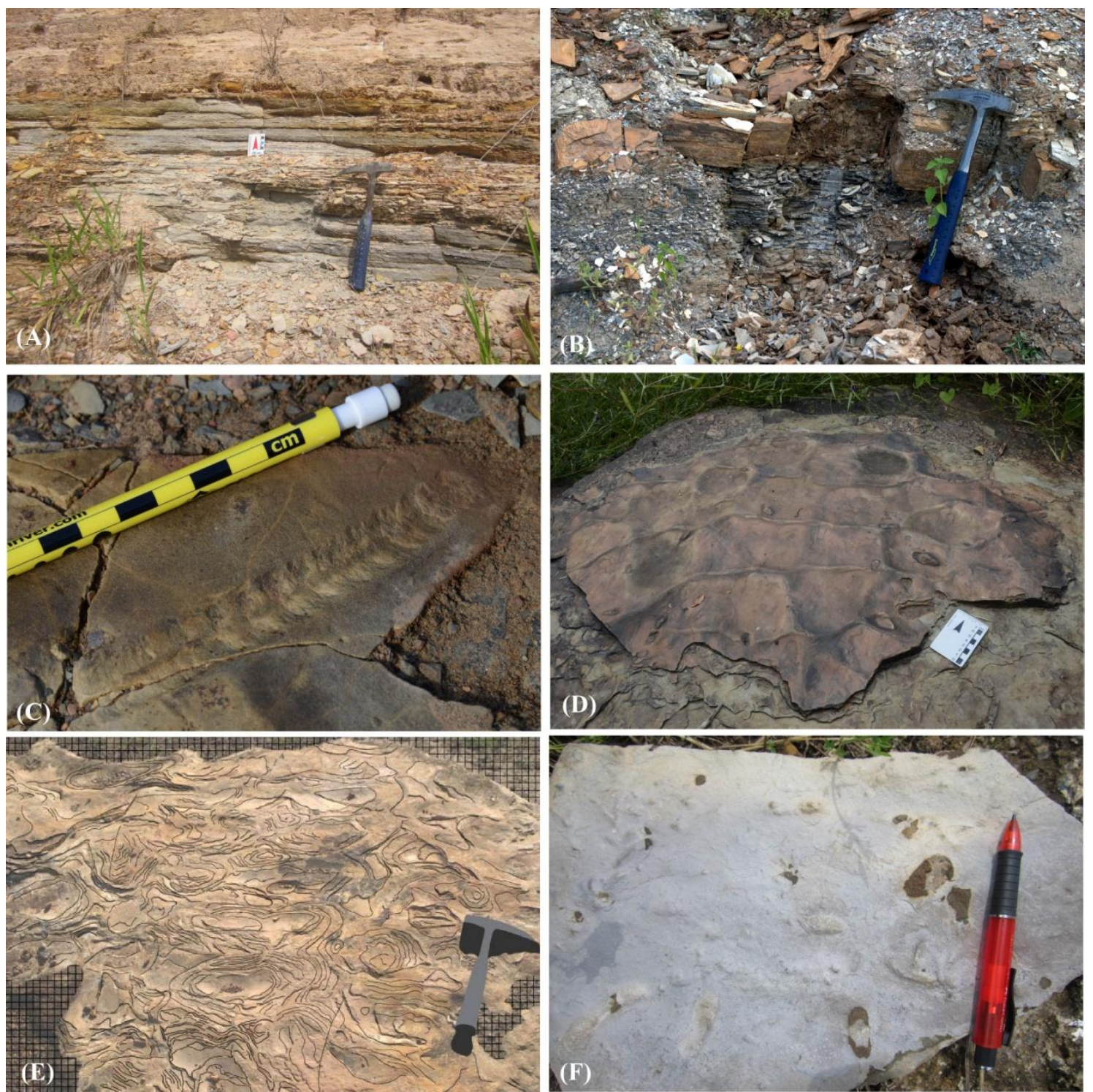

Figura 12. Folhelhos e arenitos da Formación Longá. 


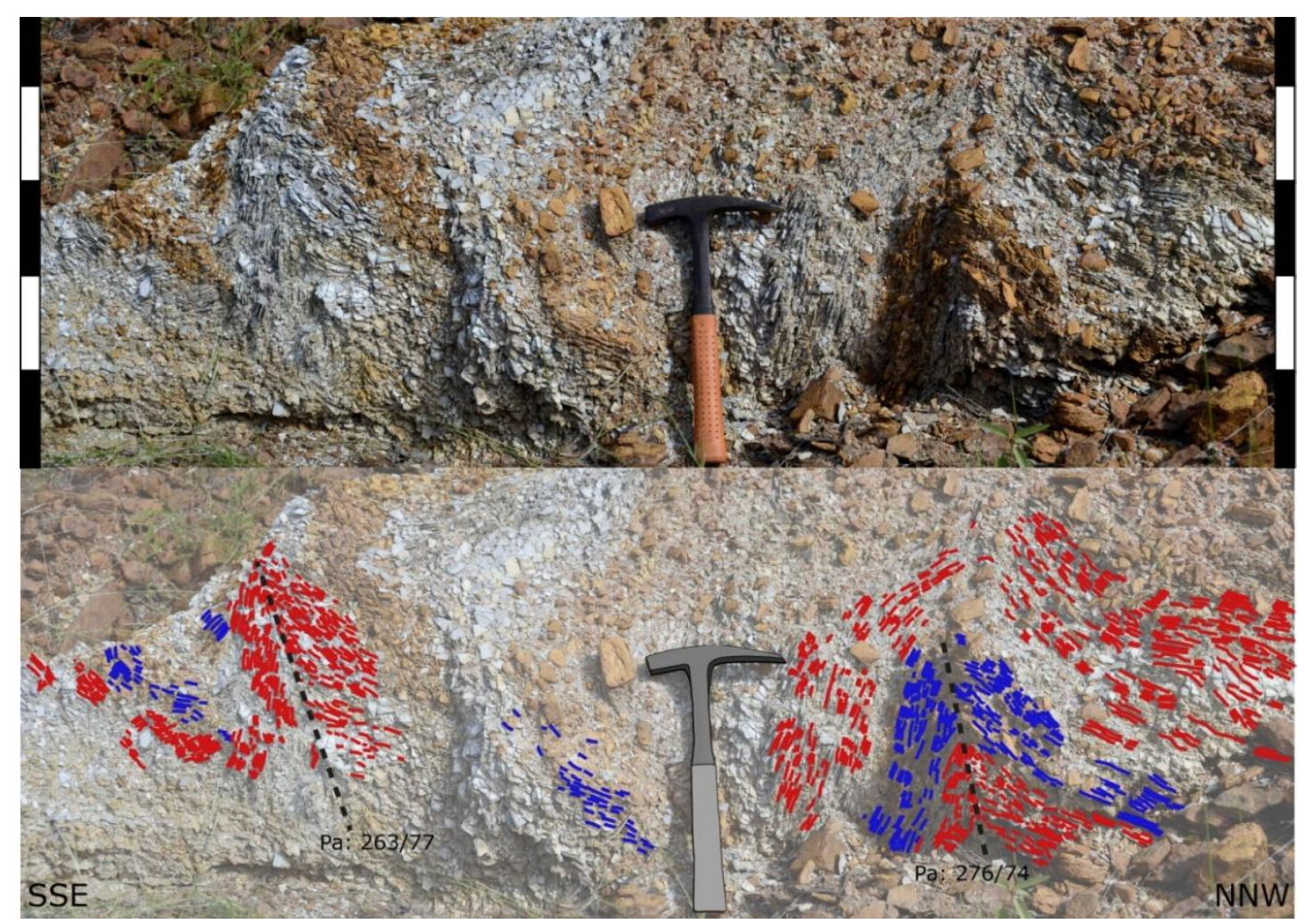

Figura 13. Folhelhos intercalados com arenitos, Formação Longá, com deformações do tipo kink band (Estação LTB-175; Pa: plano axial).

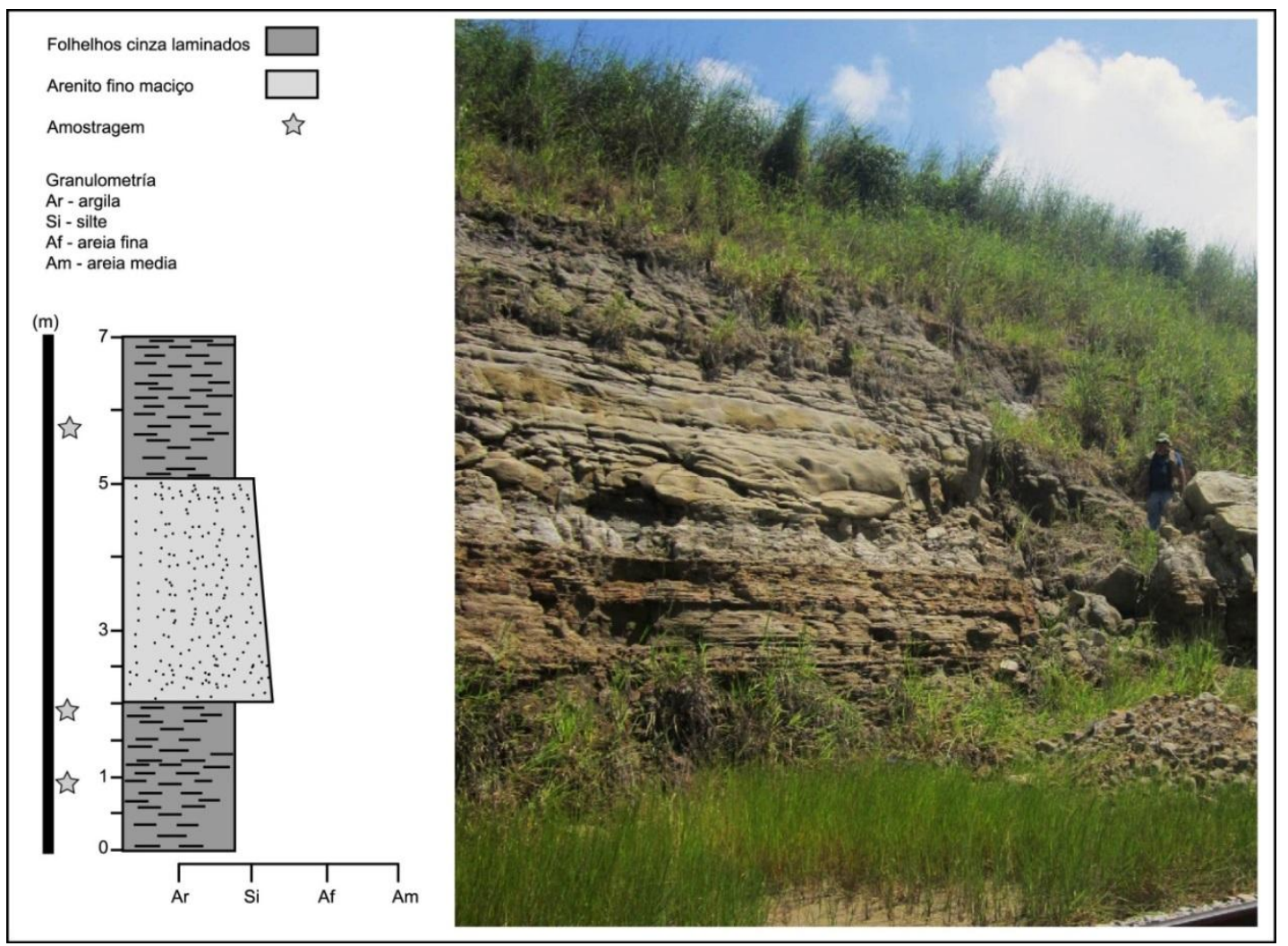

Figura 14. Folhelhos da Formação Longá, Estação LTB-223. 


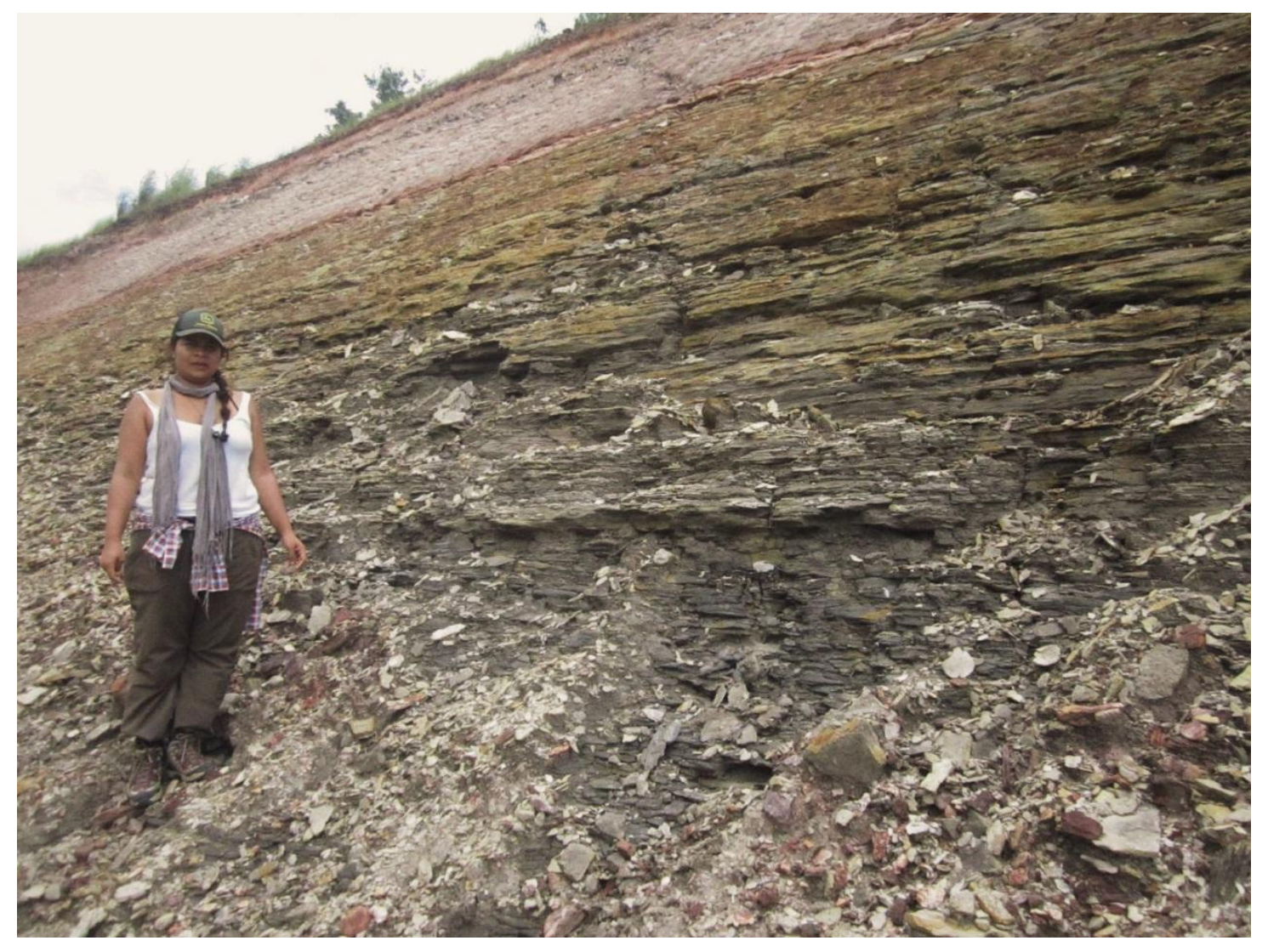

Figura 15. Folhelho cinza da Formacão Pimenteiras, Estação LTB-211.

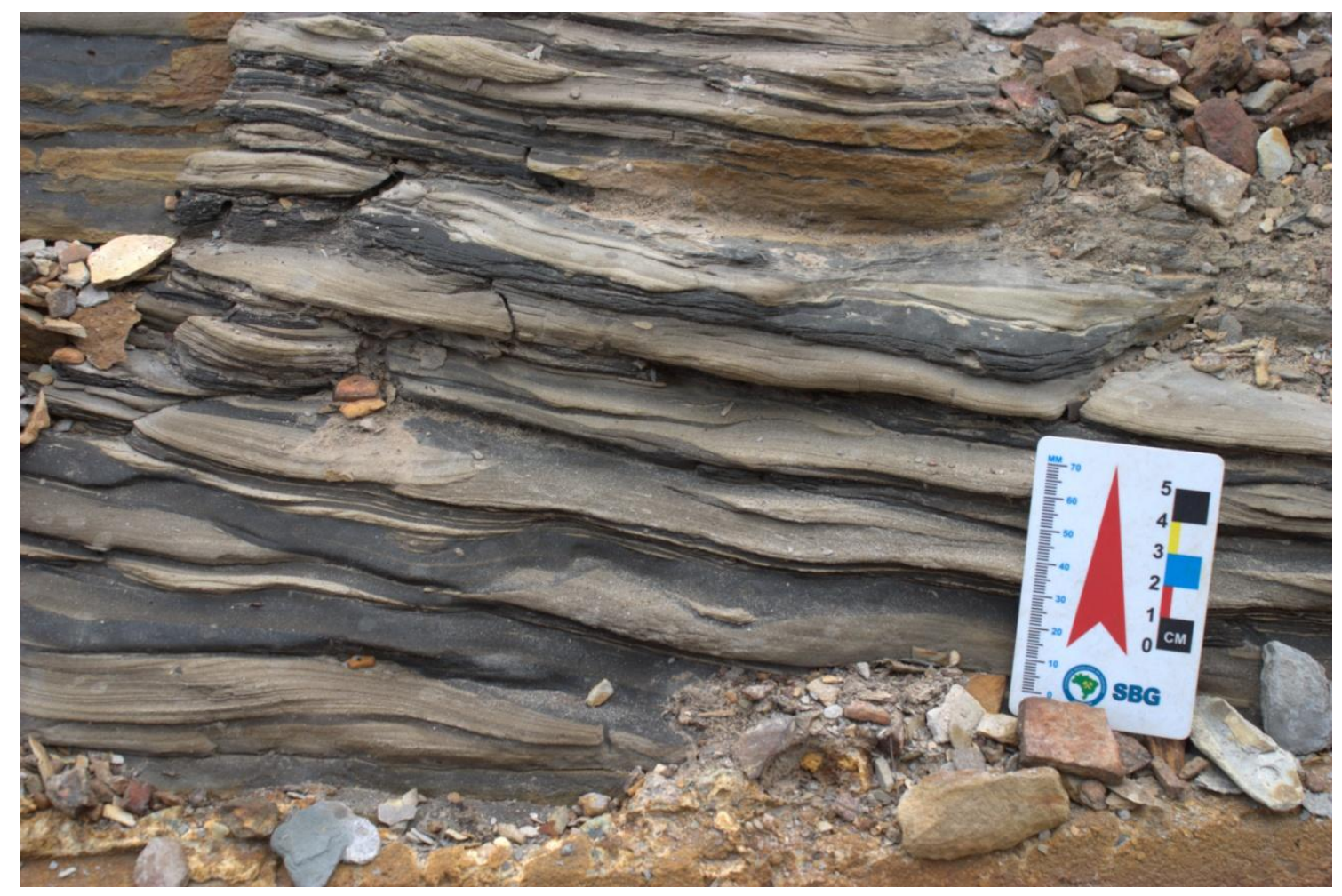

Figura 16. Detalhe dos folhelhos cinza da Formacão Pimenteiras, Estação LTB-211. 


\subsection{Microscopia electrônica de Varredura (MEV) e raios X (DRX)}

Os dados das análises de difração de raios X (DRX) e microscopia eletrônica de varredura (MEV) de amostras totais da Formação Longá mostraram diferenças entre as bordas leste e oeste. As imagens de MEV permitiram obter uma visão geral tanto da estrutura quanto da textura de folhelhos das formações Longá e Pimenteiras, coletados nas bordas leste e oeste da Bacia do Parnaíba.

Na Tabela 1 estão apresentados os minerais identificados nas amostras totais. As análises de DRX das amostras da Formação Longá coletadas na borda leste da Bacia do Parnaíba mostraram que os folhelhos são compostos por quartzo, albita, mica, clorita, calcita, dolomita e hematita.

\begin{tabular}{|c|c|c|c|c|c|c|c|c|c|c|c|}
\hline \multirow{4}{*}{ Amostra } & \multirow{4}{*}{ Formação } & \multirow{4}{*}{ Litologia } & \multirow{4}{*}{$\begin{array}{c}\text { Borda } \\
\text { da } \\
\text { Bacia }\end{array}$} & \multicolumn{8}{|c|}{ Minerais } \\
\hline & & & & \multirow[b]{3}{*}{ Q } & \multicolumn{4}{|c|}{ Silicatos } & \multirow{2}{*}{\multicolumn{2}{|c|}{ Carbonatos }} & \multirow{3}{*}{$\begin{array}{c}\text { Oxido } \\
\mathrm{He} \\
\end{array}$} \\
\hline & & & & & \multirow{2}{*}{\begin{tabular}{|c|} 
Feldspatos \\
$\mathrm{Ab}$ \\
\end{tabular}} & \multirow{2}{*}{$\frac{\text { Mica }}{\mathrm{M}}$} & \multicolumn{2}{|c|}{ Argilominerais } & & & \\
\hline & & & & & & & Chl & $\mathrm{I} / \mathrm{S}$ & $\mathrm{Ca}$ & Do & \\
\hline LTB 136 & Longá & Folhelho & \multirow{7}{*}{ Leste } & $\mathrm{X}$ & $\mathrm{X}$ & $\mathrm{X}$ & $\mathrm{X}$ & & & & \\
\hline LTB 137 & Longá & Folhelho & & $\mathrm{X}$ & $\mathrm{X}$ & $\mathrm{X}$ & $\mathrm{X}$ & & & & $\mathrm{X}$ \\
\hline LTB 156 & Longá & Folhelho & & & & $\mathrm{X}$ & $\mathrm{X}$ & & & & \\
\hline LTB 173 & Longá & Folhelho & & $\mathrm{X}$ & $\mathrm{X}$ & $\mathrm{X}$ & $\mathrm{X}$ & & $X$ & $\mathrm{X}$ & $\mathrm{X}$ \\
\hline LTB 175 & Longá & Folhelho & & & $X$ & $\mathrm{X}$ & & & & & \\
\hline LTB 176 & Longá & Folhelho & & $\mathrm{X}$ & $X$ & $\mathrm{X}$ & & & & & $\mathrm{X}$ \\
\hline $\begin{array}{ll}\text { PSG } & 031 \\
\text { LO-01 } & \\
\end{array}$ & Longá & Folhelho & & $\mathrm{X}$ & $X$ & $X$ & $\mathrm{X}$ & $\mathrm{X}$ & & $\mathrm{X}$ & \\
\hline
\end{tabular}

Tabela 1. Minerais identificados das amostras totais. Q: quartzo, plagioclásio (Ab, albita), M: mica, Chl: clorita, I/S: argilomineral interestratificado illita/esmectita, Ca: calcita, Do: dolomita e He: hematita.

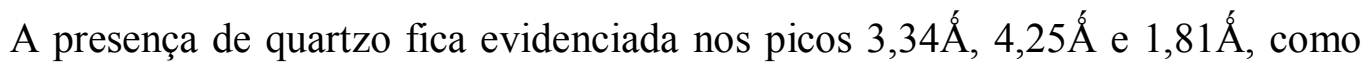
pode ser observado nos vários difratogramas, a exemplo das Figuras $17 \mathrm{C}, 17 \mathrm{~F}$ e $17 \mathrm{G}$. Observam-se os picos 6,36Á, 4,02Á e 3,18Á, que caracterizam a presença de albita, a exemplo das Figuras 17 A, 17 B e 17 D. A presença da mica na composição das

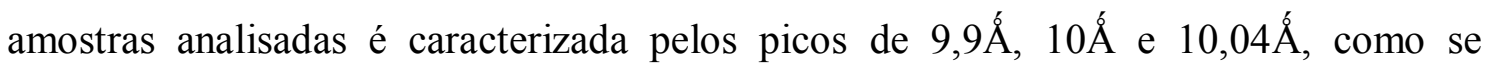
observa nas Figuras 17 A, 17 B e 16 C. A presença de clorita é evidenciada nos picos

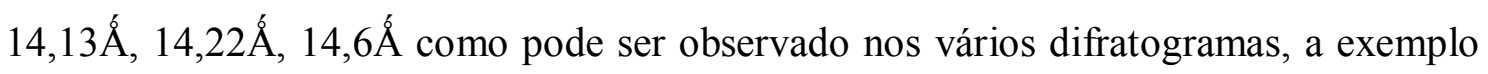
das Figuras 17A, 17 B e 17 C. Argilomineral interestratificado illita/esmectita pode ser visualizado no pico $11,32 \AA$, a exemplo da figura $17 \mathrm{G}$. A calcita pode ser visualizada no pico $3,01 \AA$ e a dolomita no pico $2,88 \AA \AA$, no difratograma da figura $17 \mathrm{D}$. Por último, a 
presença de hematita fica confirmada pelo pico $2,70 \AA$ como pode ser observado nas figuras $17 \mathrm{~B}, 17 \mathrm{D}, 1 \mathrm{~F}$. 

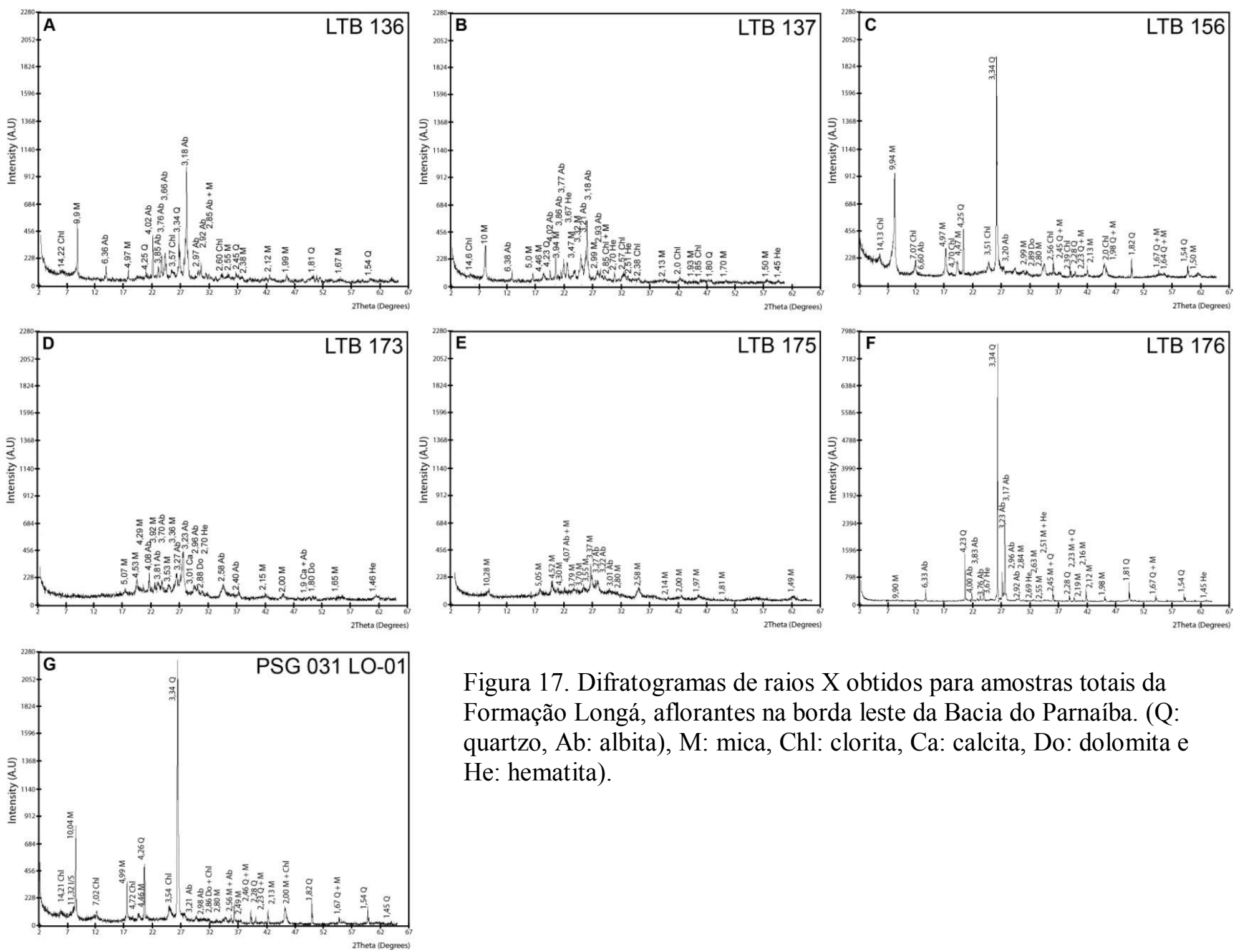

Figura 17. Difratogramas de raios $\mathrm{X}$ obtidos para amostras totais da Formação Longá, aflorantes na borda leste da Bacia do Parnaíba. (Q: quartzo, Ab: albita), M: mica, Chl: clorita, Ca: calcita, Do: dolomita e He: hematita). 
O plagioclásio da amostra LTB-136, identificado pela DRX como do tipo albita, foi confirmado usando a técnica MEV/EDS, pela presença de um pico de sódio (Na) no espectro de EDS. Este mineral apresenta bordas regulares, superfícies bem desenvolvidas e bem facetadas, e granulação silte fino (na média de $\sim 6 \mu \mathrm{m}$ ) (Figura 18). Os cristais de albita aparecem imersos na matriz e estão sendo envoltos por argilominerais e as micas.

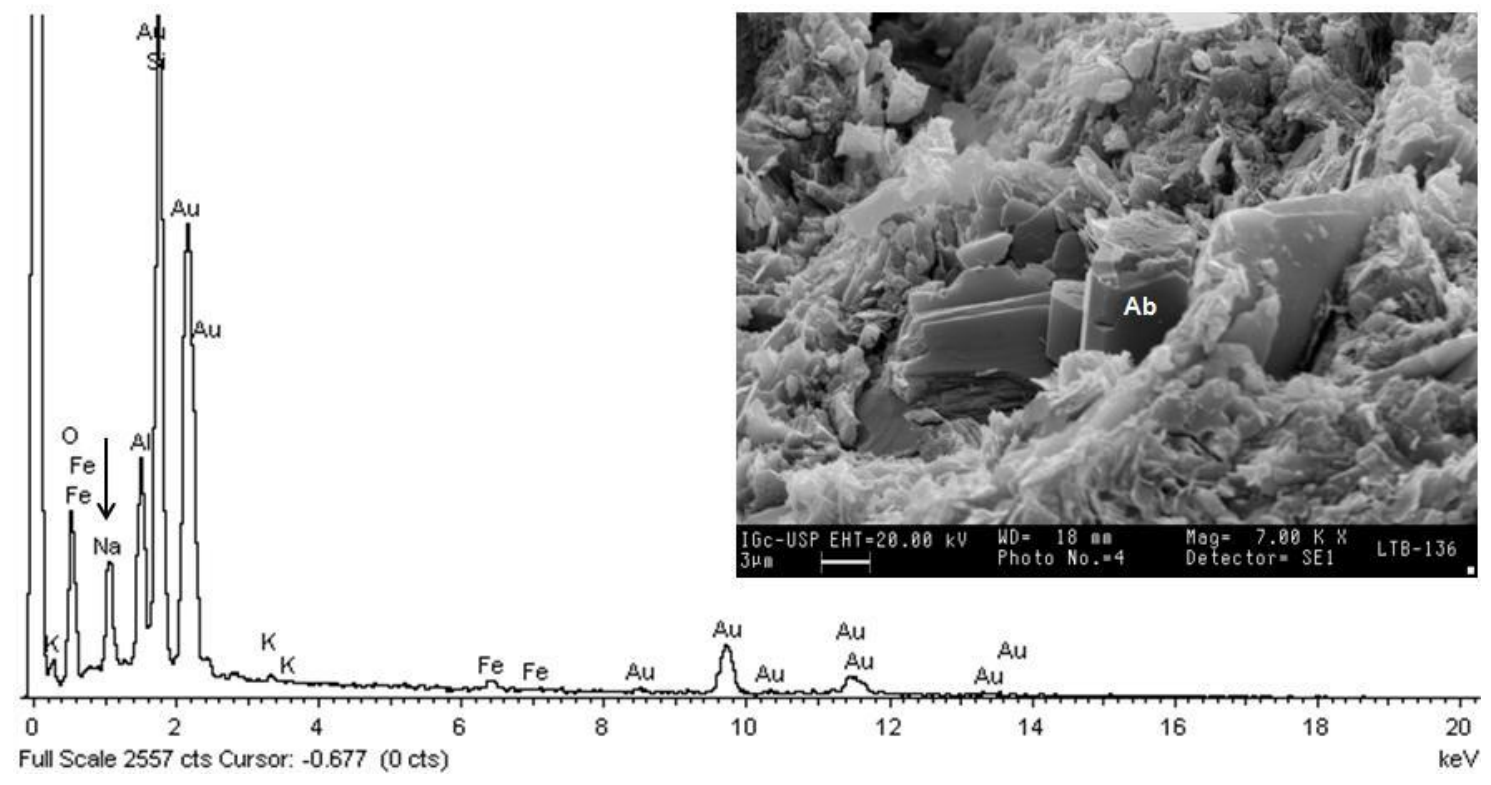

Figura 18. Espectro de EDS e imagem de MEV (SE) correspondente ao cristal de albita na parte central da imagem de MEV (Ab: albita).

O folhelho da amostra LTB-136 coletado na borda leste é composto por frações finas que variam entre silte e argila e contém minerais no tamanho areia fina $(\sim 100 \mu \mathrm{m})$. Também é possível observar na imagem de MEV uma laminação incipiente (Figura 19 A), talvez devido à presença de grãos areia provavelmente de quartzo e plagioclásio sugerido pela DRX (Tabela 2, Figura 17). As micas apresentam bordas irregulares e não estão orientadas em relação à laminação observada na imagem de detalhe de MEV (Figura 19 B) devido provavelmente aos efeitos da bioturbação sofrida pelos sedimentos. 


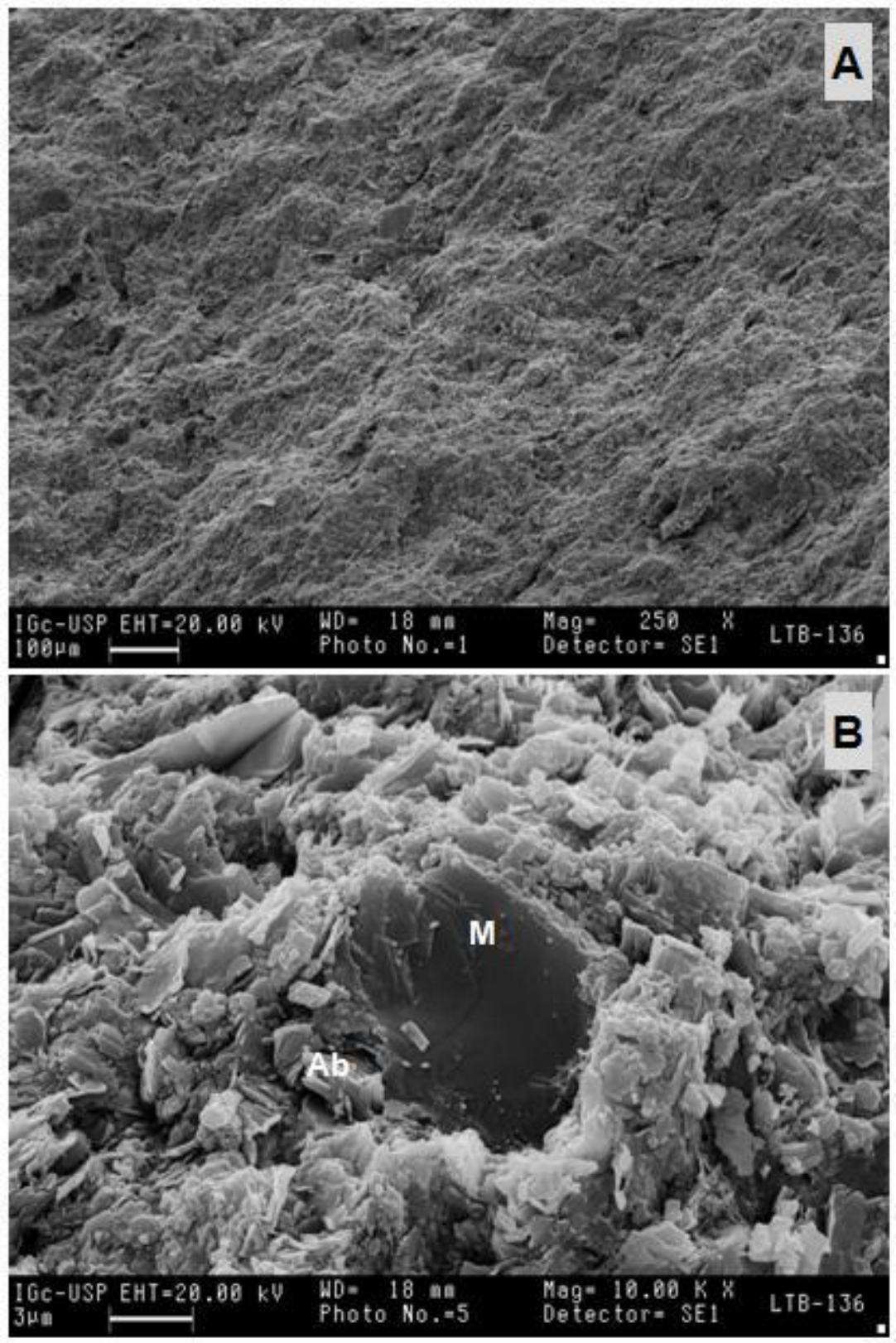

Figura 19. (A) Imagem de MEV (SE) detalhando a laminação da rocha (amostra LTB136). (B) Imagem de MEV (SE) mostrando uma placa de mica (M) com bordas irregulares.

As amostras totais da Formação Longá coletadas na borda oeste da Bacia do Parnaíba, são compostas por feldspato potássico e caulinita, além de quartzo, mica, clorita, interestratificado illita/smectita e calcita (Tabela 2). A presença de feldspato

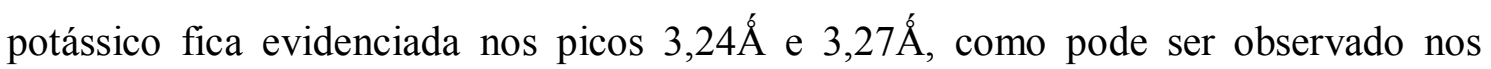
vários difratogramas, a exemplo das figuras $20 \mathrm{~B}, 20 \mathrm{C}$ e $20 \mathrm{D}$. 


\begin{tabular}{|c|c|c|c|c|c|c|c|c|c|c|}
\hline \multirow{4}{*}{ Amostra } & \multirow{4}{*}{ Formação } & \multirow{4}{*}{ Litologia } & \multirow{4}{*}{$\begin{array}{c}\text { Borda da } \\
\text { Bacia }\end{array}$} & \multicolumn{7}{|c|}{ Minerais } \\
\hline & & & & \multicolumn{6}{|c|}{ Silicatos } & \multirow{3}{*}{\begin{tabular}{|c} 
Carbonato \\
$\mathrm{Ca}$ \\
\end{tabular}} \\
\hline & & & & \multirow[b]{2}{*}{$\mathrm{Q}$} & \multirow{2}{*}{$\frac{\text { Feldspatos }}{\text { FK }}$} & \multirow{2}{*}{$\begin{array}{r}\text { Mica } \\
M\end{array}$} & \multicolumn{3}{|c|}{ Argilominerais } & \\
\hline & & & & & & & Chl & $\mathrm{I} / \mathrm{S}$ & $\mathrm{Ka}$ & \\
\hline LTB 223a & Longá & Folhelho & \multirow{4}{*}{ Oeste } & $\mathrm{X}$ & $\mathrm{X}$ & $\mathrm{X}$ & $X$ & $\mathrm{X}$ & & $\mathrm{X}$ \\
\hline LTB $223 b$ & Longá & Folhelho & & $\mathrm{X}$ & $\mathrm{X}$ & $\mathrm{X}$ & $\mathrm{X}$ & & & \\
\hline LTB 223c & Longá & Folhelho & & & $\mathrm{X}$ & $\mathrm{X}$ & & & $\mathrm{X}$ & \\
\hline MU 511 & Longá & Folhelho & & $\mathrm{X}$ & & $X$ & $X$ & & & \\
\hline
\end{tabular}

Tabela 2. Minerais identificados das amostras totais. Q: quartzo, FK: feldspato potássico, M: mica, Chl: clorita, I/S: estratificado iliita/esmectita, Ka: caulinita e Ca: calcita.
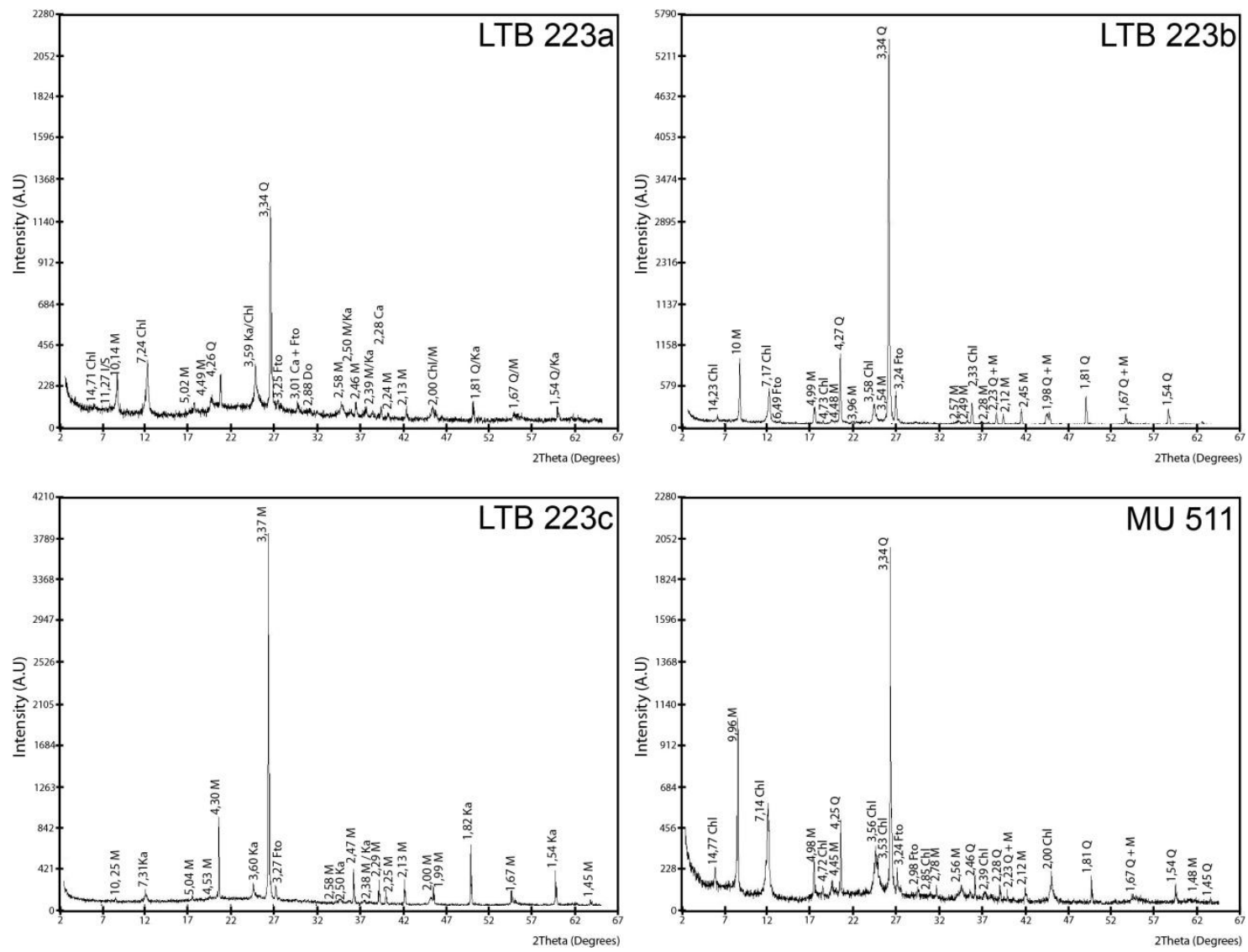

Figura 20. Difratogramas de raios X obtidos para amostra total da Formação Longá, aflorantes na borda oeste da Bacia do Parnaíba. (Q: quartzo, FK: feldspato potássico, M: mica, Chl: clorita, I/S: estratificado illita/esmectita, Ca: calcita e Do: dolomita).

A presença de caulinita não foi confirmada por tratamentos específicos para identificação desse argilomineral por DRX. Assim, nos difratogramas que apresentam os picos $14 \AA \hat{A}$ e $7 \AA ̊$, ambos foram atribuídos à clorita. Isto ocorre para a maioria das amostras da Formação Longá, sendo a exceção a amostra LTB223c. Nesta amostra a 
presença de caulinita foi apontada devido à presença dos picos 7,31 (Figura $20 \mathrm{C}$ ).

$\mathrm{Na}$ imagem de MEV da amostra LTB223a da Formação Longá, correspondente a folhelho coletado na borda oeste da Bacia do Parnaíba, se observa uma laminação melhor desenvolvida (Figura 21 A). Também é possível observar a estratificação em termos da granulação, exibindo partes mais finas (silte e argila) e camadas mais grossas (tamanho areia), como é observado na Figura 21 B. Na imagem de detalhe (Figura $21 \mathrm{C}$ ) há presença de laminações bem definidas pelos planos de superfície das micas.
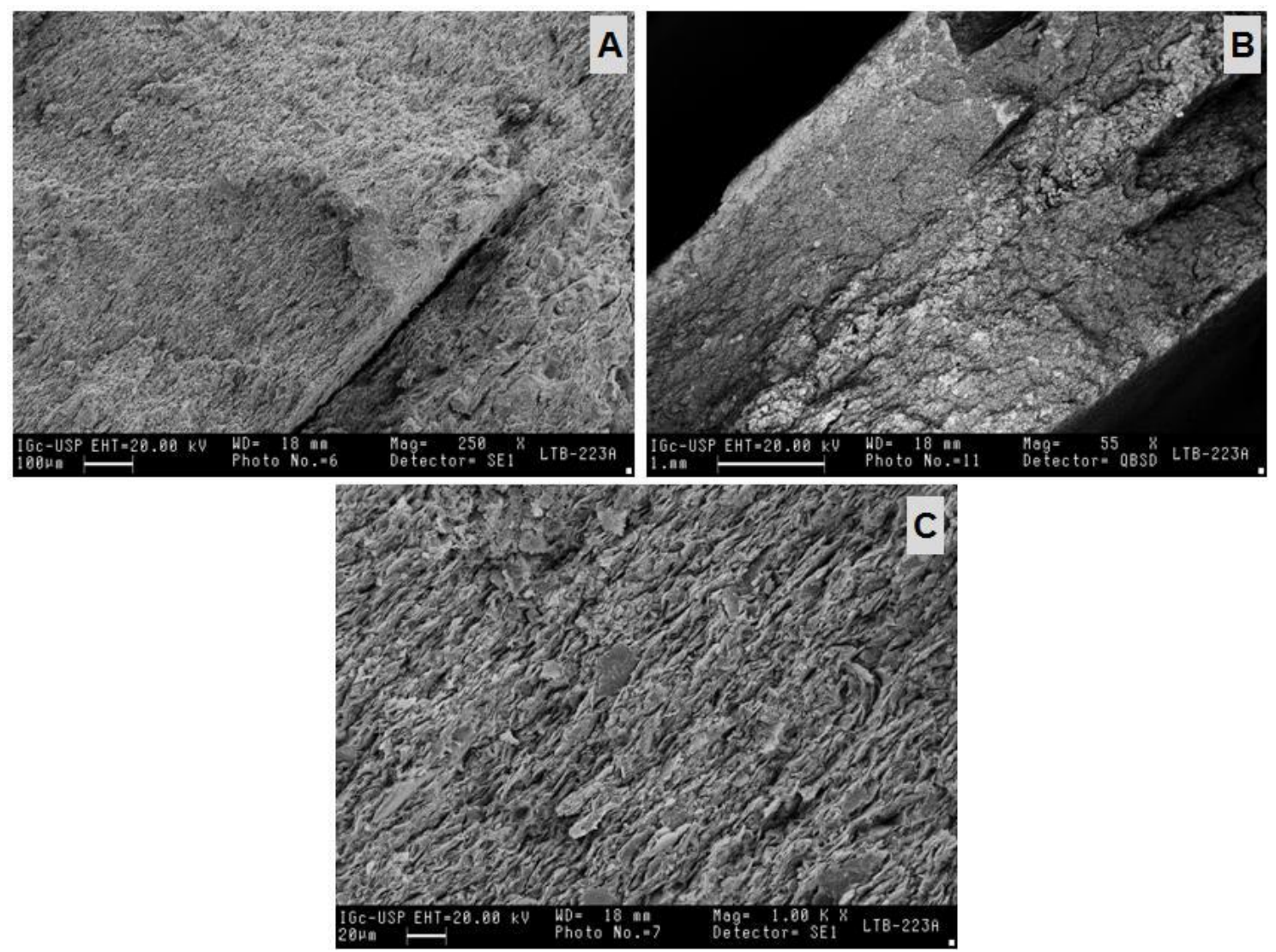

Figura 21. Imagens de MEV (A) SE, mostrando uma laminação bem desenvolvida. (B) SE, exibindo acamamento com porções mais finas (silte e argila) e mais grossas (areia). (C) SE, da matriz com presença de grãos detríticos discordantes com os planos de estratificação da rocha. (D) Imagem de MEV (sinal de elétrons secundários) em detalhe dos grãos detritícos imersos na matriz composta por argilominerais e micas. 
Segundo os resultados da DRX, estas micas apresentam espaçamentos de 10Á, como foi observado nos difratogramas da Figura 20. As análises químicas ao MEV (EDS) possibilitaram identificar sua presença espalhada na matriz da amostra (Figura 22). Além disso, na imagem MEV podem ser observadas bordas irregulares. 

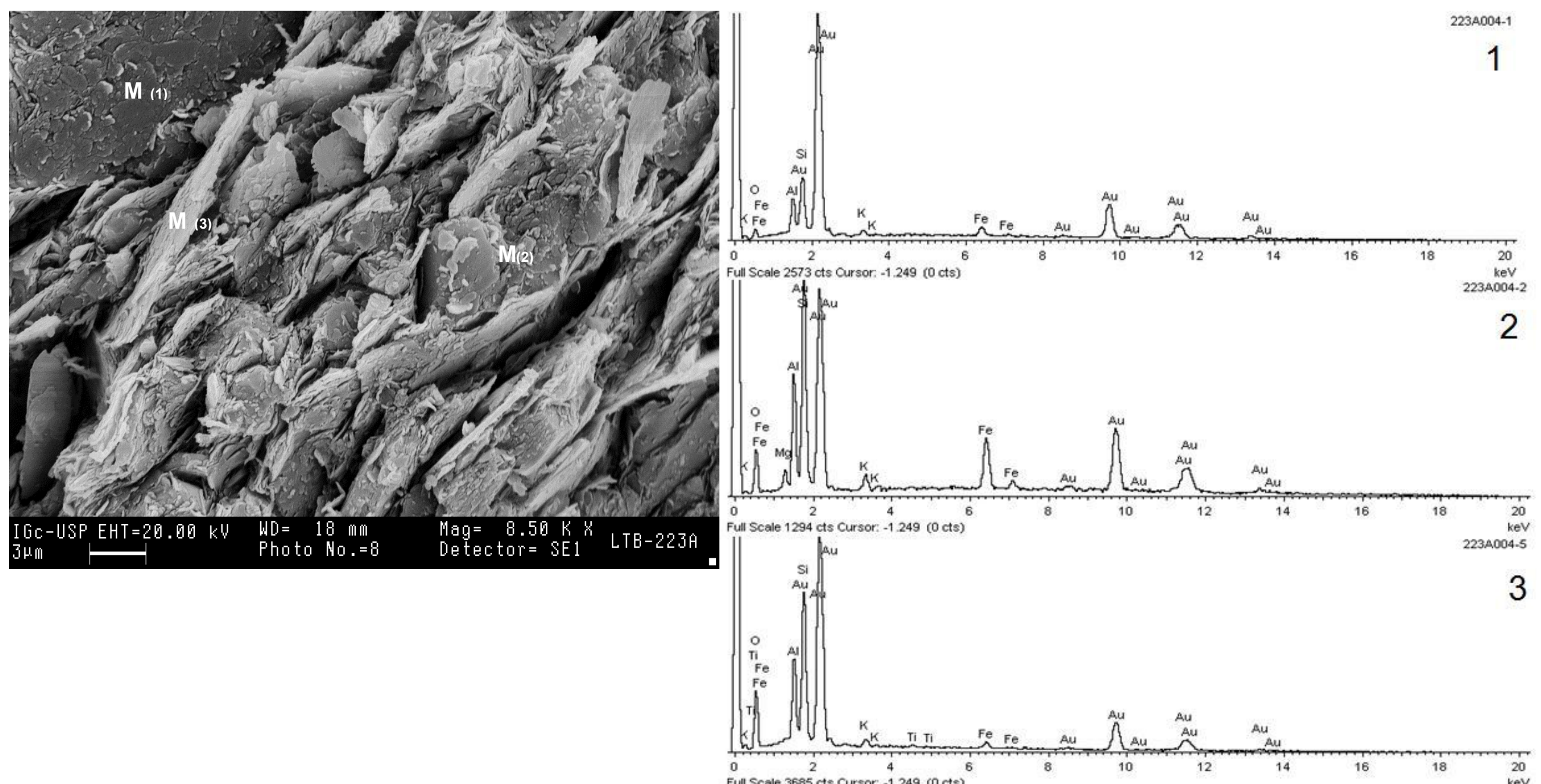

Figura 22. Imagem de detalhe de MEV (SE) com os pontos marcados para EDS, onde os difratogramas da analise MEV/EDS sugerem a presença provável de mica na matriz argilosa. 
As amostras totais da Formação Pimenteiras coletadas na borda oeste da Bacia do Parnaíba são compostas por albita, mica, caulinita calcita e dolomita (Tabela 3), como pode ser observado nos difratogramas da Figura 23.

\begin{tabular}{|c|c|c|c|c|c|c|c|c|}
\hline \multirow{4}{*}{ Amostra } & \multirow{4}{*}{ Formação } & \multirow{4}{*}{ Litologia } & \multirow{4}{*}{$\begin{array}{c}\text { Borda da } \\
\text { Bacia }\end{array}$} & \multicolumn{5}{|c|}{ Minerais } \\
\hline & & & & \multicolumn{3}{|c|}{ Silicatos } & \multirow{2}{*}{\multicolumn{2}{|c|}{ Carbonatos }} \\
\hline & & & & Feldspatos & Mica & Argilomineral & & \\
\hline & & & & $\mathrm{Pl}(\mathrm{Ab})$ & M & $\mathrm{Ka}$ & $\mathrm{Ca}$ & Do \\
\hline LTB 208 & Pimenteiras & Folhelho & \multirow{2}{*}{ Oeste } & $\mathrm{X}$ & $X$ & $\mathrm{X}$ & $\mathrm{X}$ & \\
\hline LTB 211 & Pimenteiras & Folhelho & & $\mathrm{X}$ & $\mathrm{X}$ & & $\mathrm{X}$ & $\mathrm{X}$ \\
\hline
\end{tabular}

Tabela 3. Minerais identificados das amostras totais. Plagioclásio (Ab, albita), M: mica, Ka: caulinita, Ca: calcita e Do: dolomita.
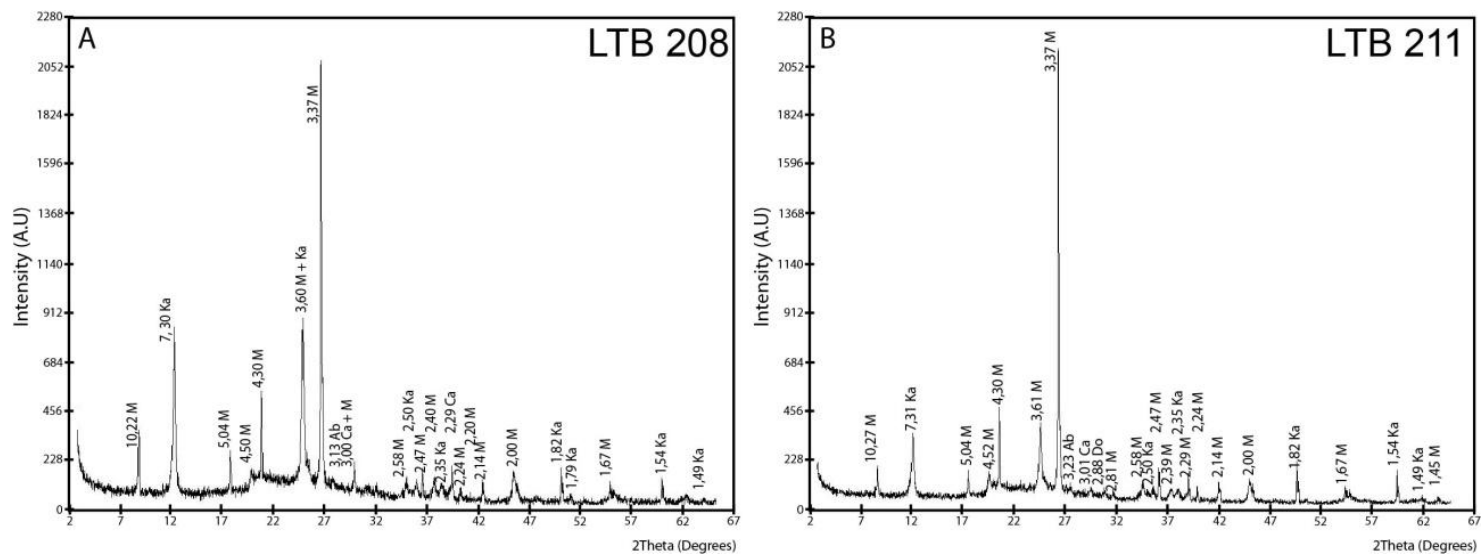

Figura 23. Difratogramas de raios X obtidos para amostras totais da Formação Pimenteiras, aflorantes na borda oeste da Bacia do Parnaíba (Ab: plagioclásio (albita), M: mica, Chl: clorita, Ka: caulinita, Ca: calcita e Do: dolomita).

Na imagem de detalhe da amostra LTB211 (Figura 24) há presença de planos de laminação e a granulação é mais grossa em relação aos folhelhos da Formação Longá. 


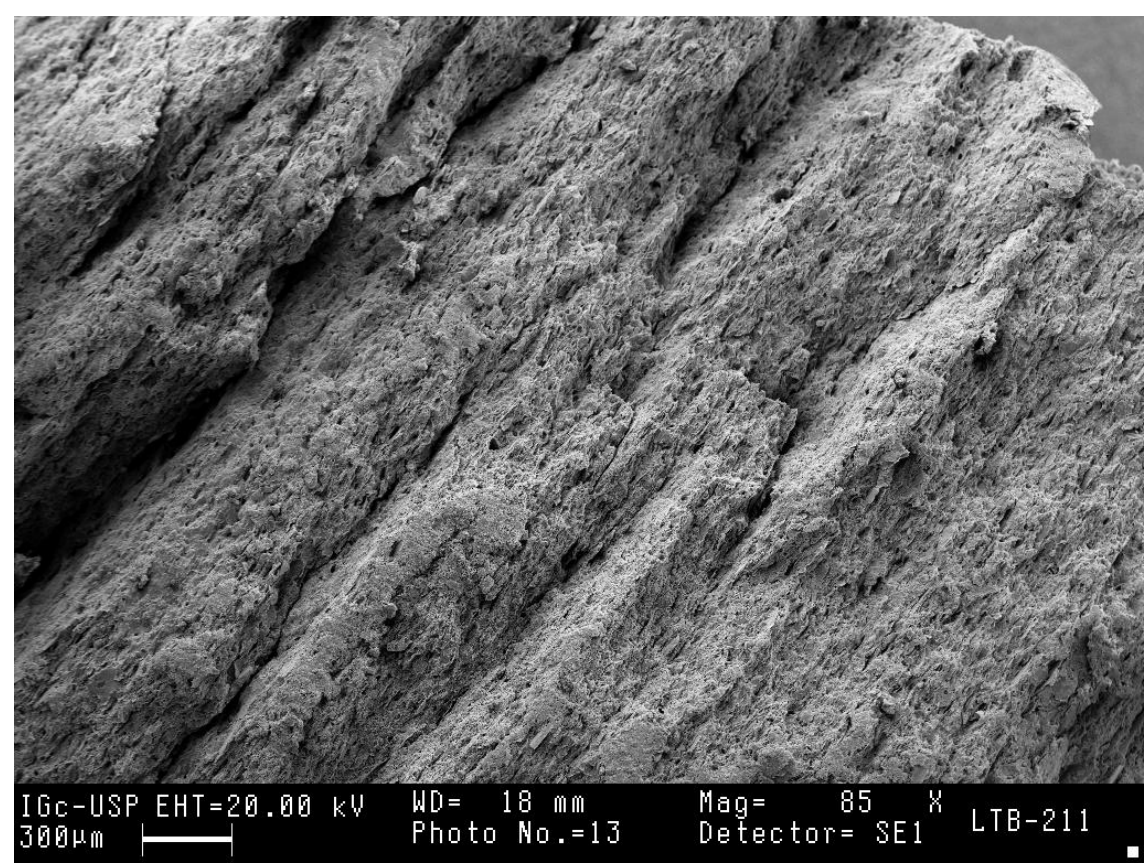

Figura 24. Imagem de MEV (SE) mostrando os planos de estratificação do folhelho da Formação Pimenteiras (amostra LTB211).

Na matriz foi identificada a presença de mica, confirmada por DRX (Figura 22), além da presença de grão de pirita sub-arredondado, com baixa esfericidade e orientado com a laminação (Figura 25).

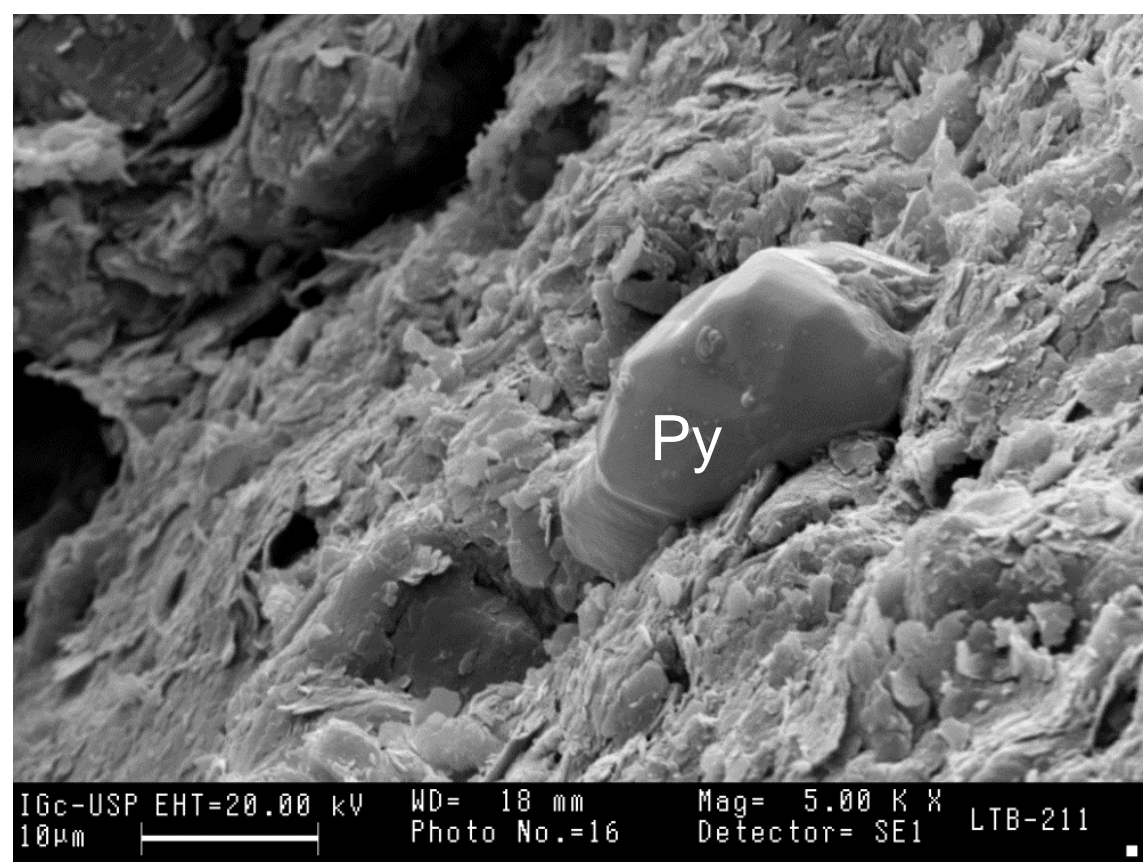

Figura 25. Imagem de detalhe de MEV (SE) mostrando a presença de pirita detrítica na matriz. 
Adicionalmente, as micas encontram-se numa posição discordante do acamamento observado no folhelho (Figura 26).
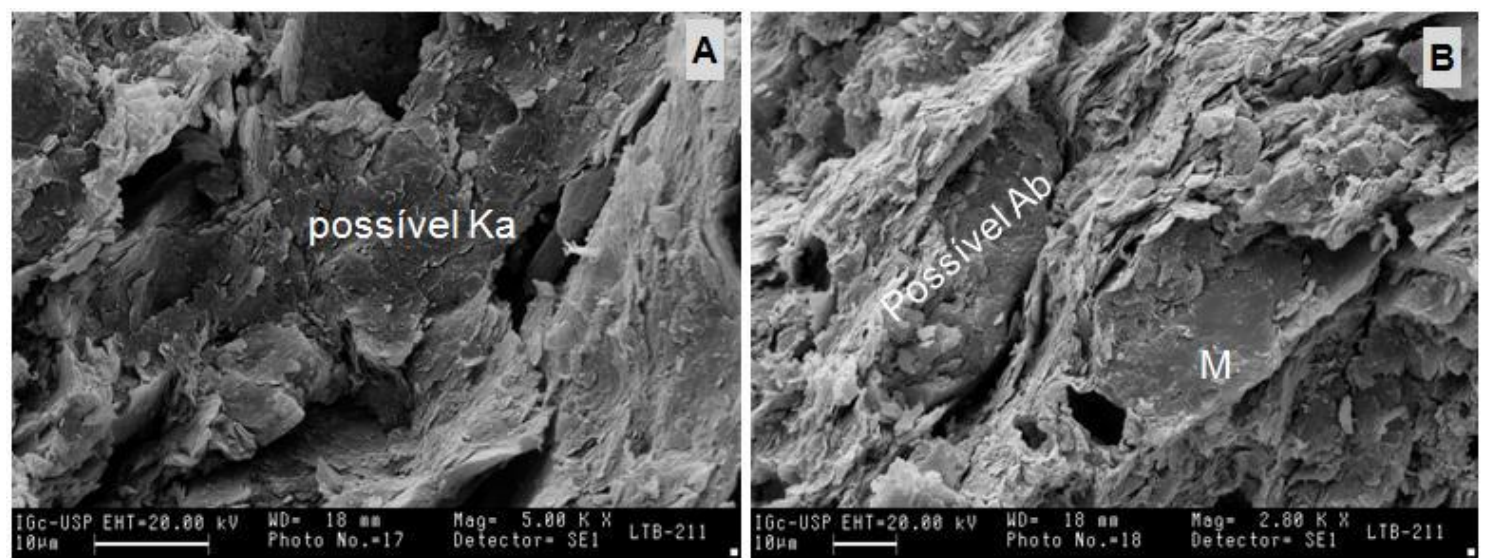

Figura 26. (A) Imagem de MEV (SE), mostrando a matriz da amostra LTB-211 com possível presença de caulinita (Ka). (B) Presença de mica $(\mathrm{M})$ e um possível grão detritico de albita $(\mathrm{Ab})$.

Finalmente, a amostra da Formação Tianguá, coletada na borda leste da Bacia do Parnaíba é composta por quartzo, feldspato potássico, mica, interestratificado illita/smectita, caulinita e dolomita (Tabela 4), como pode ser observado no difratograma da Figura 27.

\begin{tabular}{|c|c|c|c|c|c|c|c|c|c|}
\hline \multirow{4}{*}{ Amostra } & \multirow{4}{*}{ Formação } & \multirow{4}{*}{ Litologia } & \multirow{4}{*}{$\begin{array}{c}\text { Borda da } \\
\text { Bacia }\end{array}$} & \multicolumn{6}{|c|}{ Minerais } \\
\hline & & & & \multicolumn{5}{|c|}{ Silicatos } & \multirow[b]{2}{*}{ Carbonato } \\
\hline & & & & \multirow[b]{2}{*}{ Q } & Feldspatos & Mica & \multicolumn{2}{|c|}{ Argilomireral } & \\
\hline & & & & & FK & $M$ & $\mathrm{I} / \mathrm{S}$ & $\mathrm{Ka}$ & Do \\
\hline $\begin{array}{c}\text { PSG } 020 \text { TI- } \\
01\end{array}$ & Tianguá & Folhelho & Leste & $\mathrm{X}$ & $X$ & $X$ & $\mathrm{X}$ & $X$ & $X$ \\
\hline
\end{tabular}

Tabela 4. Minerais identificados na amostra total. Q: quartzo, FK: feldspato potássico, M: mica, I/S: estratificado iliita/esmectita, Ka: caulinita e Do: dolomita. 


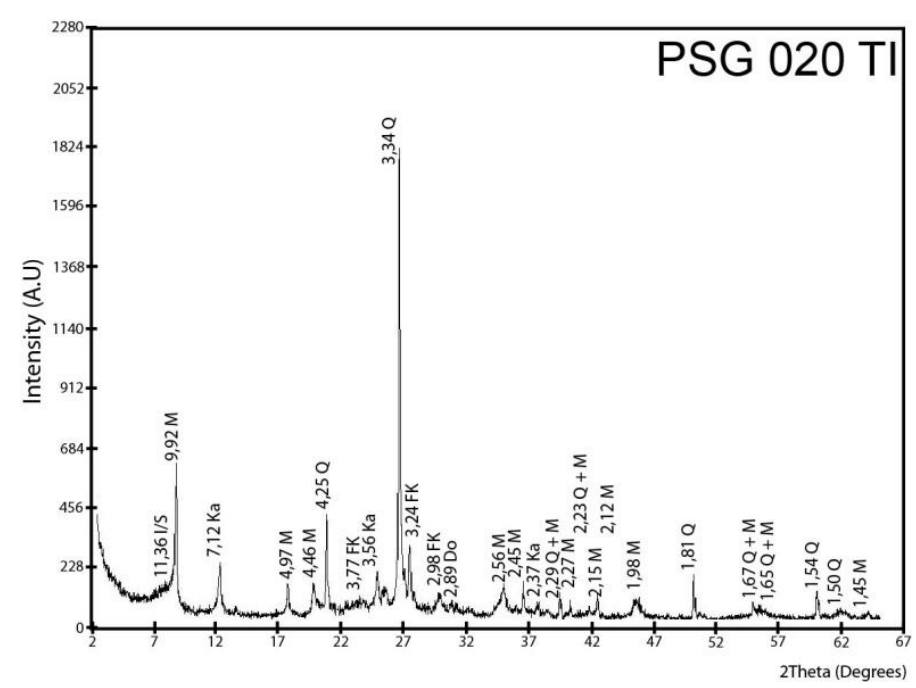

Figura 27. Difratograma de raios X obtido para amostra total da Formação Tianguá, aflorante na borda leste da Bacia do Parnaíba (Q: quartzo, FK: Feldspato, M: mica, I/S: interestratificado illita/esmectita, Ka: caulinita, e Do: dolomita).

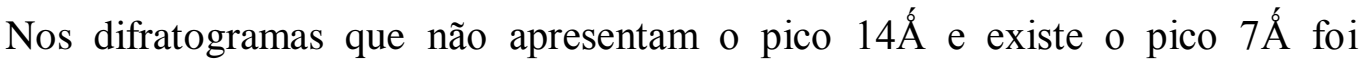
indicada a presença de caulinita, sendo o caso das amostras das formações Pimenteiras e Tianguá (Figuras 23 e 27).

\subsection{Carbono orgânico total (COT)}

As amostras da Formação Longá coletadas na faixa de afloramentos leste da Bacia do Parnaíba apresentaram valores de COT entre $0,33 \%$ e $0,02 \%$. Na faixa de afloramentos da parte oeste da bacia os terrores de COT variaram entre 0,61\% e 0,05\% (Figura 28, Tabela 5). As amostras da Formação Pimenteiras, coletadas exclusivamente na faixa de afloramentos oeste, apresentaram teores de COT variando entre 0,68 e 1,55 \% (Tabela 6). Nas formações Poti, na faixa leste, e Cabeças, na faixa oeste de afloramentos, os valores encontrados foram muito baixos, de 0,21\% e 0,11\%, respectivamente (Tabela 6). 


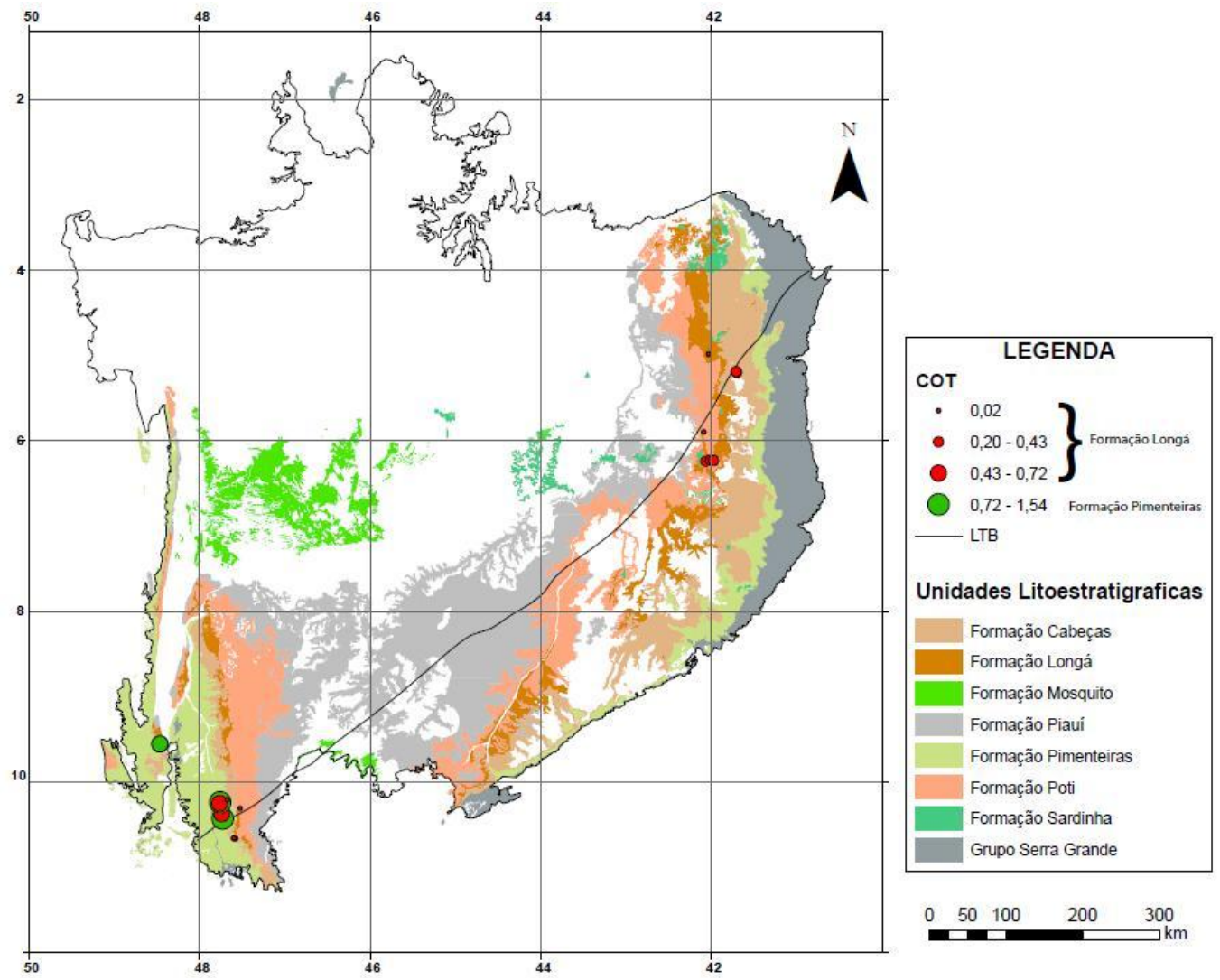

Figura 28. Distribução espacial dos valores de COT (em \%) nas amostras da Formação Longá coletadas na Bacia do Parnaíba.

\begin{tabular}{|l|l|l|r|}
\hline Amostra & Formação & Borda & \%Carbono \\
\hline LTB 173 & Longá & Leste & 0,33 \\
\hline LTB 156 & Longá & Leste & 0,31 \\
\hline LTB136 & Longá & Leste & 0,30 \\
\hline LTB 158 & Longá & Leste & 0,28 \\
\hline LTB 175 & Longá & Leste & 0,22 \\
\hline LTB 137 & Longá & Leste & 0,09 \\
\hline LTB 157 & Longá & Leste & 0,07 \\
\hline LTB 176 & Longá & Leste & 0,02 \\
\hline PSG 031 LO-01 & Longá & Leste & $?$ \\
\hline LTB 223a & Longá & Oeste & 0,61 \\
\hline LTB 223c & Longá & Oeste & 0,52 \\
\hline LTB 222 & Longá & Oeste & 0,43 \\
\hline LTB 223b & Longá & Oeste & 0,39 \\
\hline LTB 206 & Longá & Oeste & 0,14 \\
\hline LTB 205 & Longá & Oeste & 0,13 \\
\hline LTB 012 & Longá & Oeste & 0,11 \\
\hline LTB 204 & Longá & Oeste & 0,05 \\
\hline
\end{tabular}

Tabela 5. Resultados de teores de carbono orgânico total e hidrogênio para as amostras totais da Formação Longá. Dados em \% de peso. 


\begin{tabular}{|l|c|l|r|}
\hline \multicolumn{1}{|c|}{ Amostra } & Formação & Borda & \% Carbono \\
\hline LTB 166 & Poti & Leste & 0,21 \\
\hline LTB 214 & Cabeças & Oeste & 0,11 \\
\hline LTB 208 & Pimenteiras & Oeste & 1,55 \\
\hline LTB 211 & Pimenteiras & Oeste & 1,33 \\
\hline LTB 209 & Pimenteiras & Oeste & 0,73 \\
\hline LTB 212 & Pimenteiras & Oeste & 0,68 \\
\hline
\end{tabular}

Tabela 6. Resultados de teores de carbono orgânico total e hidrogênio para as amostras totais das formações Poti, Cabeças, Pimenteiras e Tianguá. Dados em \% de peso. 


\section{Discussão dos resultados}

\subsection{Composição mineralógica das rochas}

Um aspecto notável da Formação Longá é a presença de feldspato potássico somente em amostras coletadas na faixa oeste de afloramentos, enquanto nas amostras da faixa leste ocorre exclusivamente plagioclásio (albita).

O feldspato potássico foi identificado por DRX, mas não foi observado ao MEV. Em imagem de MEV a albita mostrou bordas regulares e superfícies bem desenvolvidas e facetadas, sugerindo origem autigênica (Figura 18). A amostra analisada ao MEV (LTB-136) encontra-se na área de influência de rochas básicas intrusivas da Formação Sardinha, o que permite especular que a autigênese possa ter relação com a circulação de fluídos associados ao evento magmático. É provável que as altas temperaturas tenham influenciado o início da autigênese da albita (Oshchudlak \& Hubert 1988). Há registro de albita autigênica formada entre $80^{\circ} \mathrm{C}$, em arcósios do Paleógeno da Califórnia (Helmold \& van de Kamp 1984), a até mais de $150^{\circ} \mathrm{C}$, em arenitos terciários da costa do Golfo do México, no Texas (Boles 1982).

Alternativamente, a presença de albita pode ser resultante da substituição de feldspato potássico. Saigal et al. (1988) descreveram o processo de albitização do feldspato potássico, mediante mecanismo de dissolução-precipitação, em função da diagênese por soterramento, sendo que a taxa de precipitação da albita aumenta com a profundidade. Neste caso poder-se-ía admitir maior grau de soterramento para a parte leste da Bacia do Parnaíba em relação à parte oeste.

A amostra MU-511 é a única obtida a partir de sondagem, na Cratera de Serra da Cangalha. Ela apresenta como caraterística particular a ausência de feldspatos, o que pode estar ligado a maior profundidade de soterramento do Folhelho Longá.

Quartzo não foi detectado em amostras de folhelhos da Formação Pimenteiras, coletadas na faixa oeste de afloramentos. Também não foi detectado em algumas amostras da Formação Longá, coletadas tanto na faixa leste (LTB-156, 175) como na faixa oeste (LTB-223c) de afloramentos.

Caulinita ocorre somente em folhelho da parte superior do perfil LTB-223 (amostra LTB-223c), tendo sido indentificada por DRX. Por se tratar da porção mais 
superficial do perfil é possível que sua presença seja resultado de processos de alteração intempérica.

A presença de interestratificados I/S foi constatada pela análise de DRX em amostras da Formação Longá, coletadas nas faixas de afloramento leste (amostra PSG031 LO-01) e oeste (amostra LTB-223a), neste último caso na base de uma seção colunar. Na formação Tianguá (amostra PSG 020 TI-01) também foi detectada a presença de interestratificado I/S por DRX.

Clorita apresenta distribuição generalizada na Formação Longá, nas faixas leste e oeste de afloramentos. Em imagens de MEV as micas mostram bordas irregulares. Além disso, arranhões mecânicos não foram observados nas superfícies das placas com exposição favorável. Essas características evidenciam origem detritíca a partir de fontes continentais para as micas (Park \& Pilkey 1981).

A presença de hematita foi constatada por DRX no folhelho da Formação Longá, mas sua natureza detrítica ou autigênica não pode ser comprovada por observação em microscópio eletrônico de varredura. Hematita é um constituinte comum em rochas sedimentares, forma-se sob condições oxidantes de intemperismo tropical, subtropical e temperado (Parrish 1998). Por outro lado, o ferro pode ser lixiviado das rochas hospedeiras, pela circulação de fluídos em faixas de maior porosidade e permeabilidade, e a hematita depositada quando o fluído contendo o ferro reduzido encontra condições oxidantes, processos que podem ser facilitados pela presença de compostos orgânicos (Ormö et al. 2004). No caso da Formação Longá, a circulação de fluídos é facilitada pela presença de lâminas a camadas de arenito intercalados nos folhelhos.

Na Formação Pimenteiras ocorre pirita em grão subarredondado, com baixa esfericidade e acomodado na laminação, indicando origem detrítica. Sob condições de baixa concentração de $\mathrm{O} 2$ os grãos de pirita são submetidos à abrasão unicamente por processos físicos, em decorrência do transporte (v.g. Johnson et sal. 2014). Dessa forma, a presença de pirita detrítica em sedimentos tem sido considerada como um indicador consistente de condições anóxicas durante a deposição (v.g. Fleet 1998).

\subsection{Avaliação da distribuição de COT}

Dentro das características necessárias para avaliar um sedimento como rocha geradora de hidrocarbonetos, a quantificação da matéria orgânica se constitui em um 
dos primeiros parâmetros analisados. Um constituinte orgânico se comporta como uma partícula sedimentar, ou seja, sua tendência de distribuição está condicionada aos processos sedimentares que atuam no transporte e deposição da matéria orgânica sedimentar, tais como o tectonismo, magmatismo, mudanças no nível relativo do mar, aporte sedimentar e o clima.

A quantidade de matéria orgânica medida, empregando-se o teor de carbono orgânico total (COT), reflete as condições de produção e preservação no ambiente deposicional. Considera-se o valor mínimo de $1 \%$ de COT para que uma rocha seja considerada como potencial geradora de petróleo (Tissot \& Welte 1984).

As amostras de folhelhos da Formação Longá analisadas apresentaram teores de COT muito baixos para serem consideradas como geradoras de petróleo (Tabela 5). Os maiores teores de matéria orgânica na Formação Longá foram medidos em amostras coletadas ao longo da faixa oeste de afloramentos, atingindo 0,61\% (amostras LTB223a, b e c). Na faixa leste os teores são menores e atingem 0,33\% (amostra LTB-173).

Os baixos valores podem estar associados à conversão e/ou eliminação do carbono orgânico sob o efeito do calor oriundo de corpos intrusivos, o que promoveu craqueamento da matéria orgânica reduzindo seus valores em relação às quantidades originais (Tissot \& Welte 1984), já que volumes de magma posicionados entre ou sobre os sedimentos influenciam diretamente nos processos de subsidência, compactação, diagênese e estruturação da bacia, além de impactar nos processos associados aos sistemas petrolíferos (Conceição et al. 1993). A Bacia do Parnaíba sofreu os efeitos de dois pulsos magmáticos distintos, bem representados pelas formações Mosquito e Sardinha. A Formação Mosquito (Jurássico Inferior) é descrita como grandes derrames e soleiras de basaltos toleíticos que abrangem principalmente a porção oeste da bacia, e estaria associada ao rifteamento e formação do Oceano Atlântico Central. A Formação Sardinha (Cretáceo Inferior) ocorre predominantemente na forma de pequenas soleiras e extensos diques de diabásio na porção leste da bacia, alinhadas com estruturas de direção NE-SW (Vaz et al. 2007). Comparados com o sistema de falhas com orientação NE-SW, com destaque para a zona de cisalhamento de mesma orientação a sudeste da bacia, esses diques poderiam estar associados ao Lineamento Transbrasiliano, também de direção NE-SW (Chamani 2011). 
Os maiores teores de COT encontrados na Formação Longá estão em amostras que apresentam calcita e dolomita, o que pode sugerir maior preservação frente aos processos intempéricos. As amostras com teor mais baixo contém hematita, que pode ser constituinte deposicional da própria rocha ou autigênica e relacionada a processos superficiais.

Para a Formação Longá não há relação evidente entre os teores de COT e a proximidade de rochas básicas intrusivas. Por outro lado, as amostras com teores mais baixos, seja na faixa leste (LTB-137, com 0,09\%, LTB-175, com 0,22\% e LTB-176, com $0,02 \%$ ), seja na faixa oeste (LTB-204, com 0,05\%, LTB-205, com 0,13\% e LTB206, com 0,14\%), encontram-se na área de influência do Lineamento Transbrasiliano.

Para a faixa leste de ocorrência da Formação Pimenteiras o processo de maturação da matéria orgânica teria sido influenciado pela intrusão de diques e soleiras de diabásio das formações Mosquito e Sardinha, o que pode ser verificado pela tendência positiva entre o aumento da reflectância da vitrinita (\%Ro) e a proximidade do contato com o diabásio (Góes et al. 1990, Rodrigues 1995 - Figura 30). Os principais folhelhos geradores nesta formação são radioativos e apresentam concentrações médias de COT da ordem de $2 \%$ até picos de $6 \%$ (Rodrigues 1995). Nos folhelhos da Formação Pimenteiras em contato com intrusões magmáticas, os valores de reflectância são superiores ao ponto crítico da interface óleo-gás (aproximadamente 1,35). Desta forma, é esperado que o sistema petrolífero da Bacia do Parnaíba seja propicio para geração de gás (Rodrigues 1995, Souza 2007).

No presente trabalho, os valores de COT obtidos em amostras de folhelhos de folhelhos da Formação Pimenteiras, coletadas na faixa oeste de afloramentos, variaram de $0,68 \%$ a $1,55 \%$ (Tabela 6). Esses valores são substancialmente inferiores aqueles verificados na parte leste da bacia. Assim, da mesma forma que no caso dos folhelhos da Formação Longá, a proximidade das amostras coletadas na Formação Pimenteiras com a zona de influência do Lineamento Transbrasiliano pode ter sido um fator responsável pelos teores de COT relativamente mais baixos. 


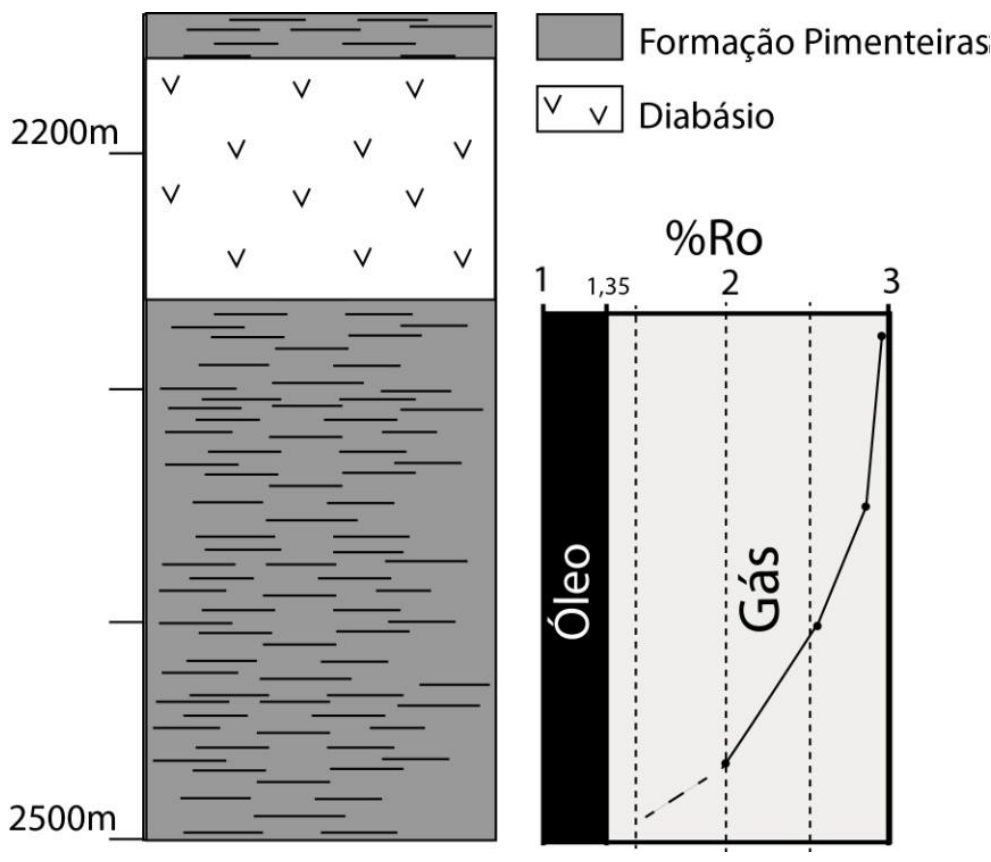

Figura 29. Esquema simplificado das intrusões de rochas magmáticas nos folhelhos da Formação Pimenteiras, mostrando-se como o principal mecanismo para maturação de matéria orgânica (segundo Rodrigues 1995).

As demais formações, Poti e Cabeças, apresentaram teores de COT de 0,21\% e 0,11\% (Tabela 6). Essas variações nos valores podem estar associadas a diferenças nas condições deposicionais e de conservação da matéria orgânica.

Os folhelhos da Formação Longá apresentam composição siliciclástica, possivelmente fruto da proximidade da área fonte, de soerguimento tectônico, e de variações glácio-eustáticas. As análises por MEV mostraram a presença de material siliclástico de origem detritica relacionado possivelmente às terras emersas do Gondwana, que estavam sendo erodidas durante a deposição da Formação Longá.

Com base em evidências faunísticas, o pólo Sul, durante o Devoniano Inferior/Médio, esteve posicionado em algum lugar próximo ao sudeste ou centro-oeste da África. Portanto climas temperados ocorreram no que hoje são as bacias do Amazonas e Parnaíba. O clima parece ter sido um fator importante no controle dessas fácies depositadas em resposta ao posicionamento do continente Gondwana, nesse tempo (Torsvik \& Cocks 2011 - Figura 31). No Fameniano, a movimentação do supercontinenete Gondwana no rumo do pólo Sul resultou na queda de temperatura, formação de geleiras e rebaixamento eustático do nível do mar da ordem de $100 \mathrm{~m}$ (Nunn \& Aires 1988). 


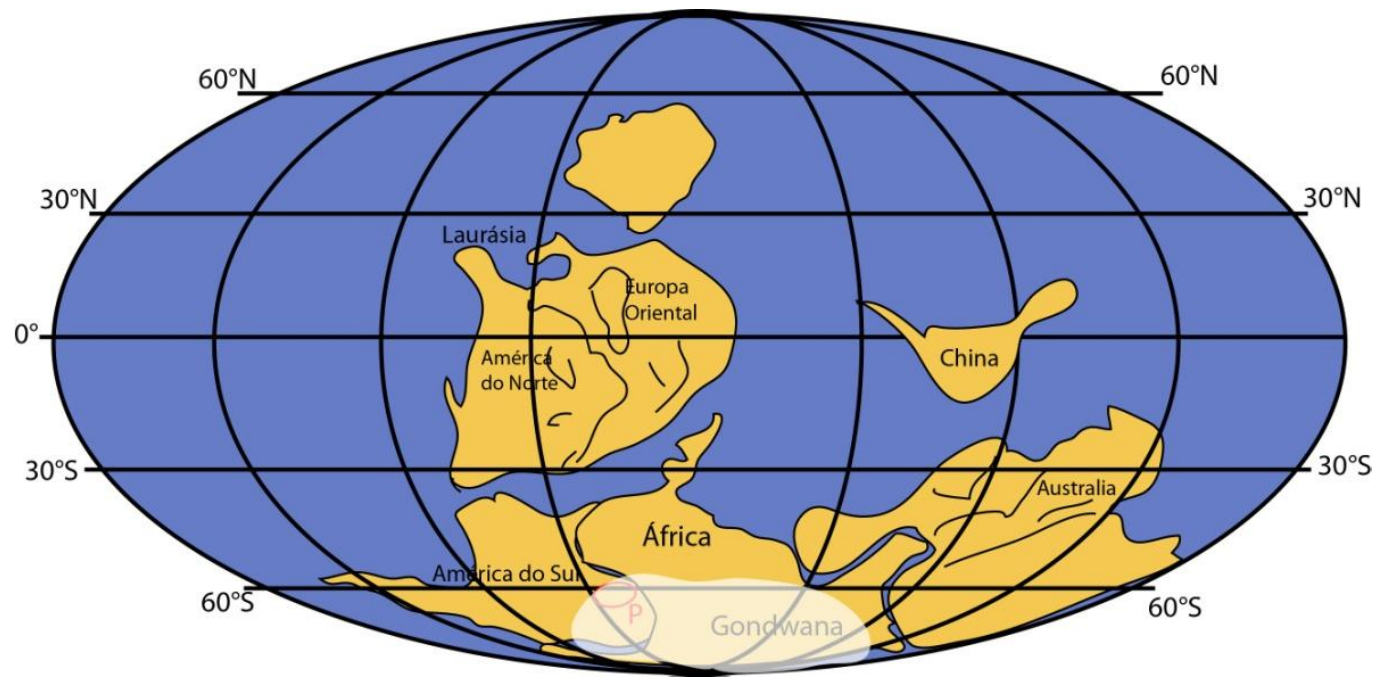

Figura 30. Paleogeografia do Gondwana no intervalo Mesodevoniano a Eeocarbonífero. Note-se a presença de massas emersas do Gondwana e a implantação da geleira. P, destaca a posição aproximada da Bacia do Parnaíba (Modificado de Torsvik \& Cocks 2001).

O período Devoniano esteve submetido à transgressões de mares rasos e ao surgimento de fauna típica de ambientes neríticos (Cooper 1977), representado pela faunas de ambiente marinho raso na Bacia do Parnaíba (Kegel 1953). As causas ainda são muito discutidas, mas mesmo que tenham sido ações conjuntas de longo prazo, acredita-se que a maior influência das glaciações foi a desestabilização do ciclo do carbono pela contínua adição de metano na atmosfera, que diminuiu os valores de isótopo de ${ }^{13} \mathrm{C}$, resfriando o clima e levando a uma glaciação (Schrag et al. 2002). Dessa maneira, as mudanças climáticas também afetaram a produção de biomassa, o que pode estar se refletindo nas variações de quantidade de matéria orgânica presente nos folhelhos das formações devonianas estudadas. 


\section{Conclusões}

A motivação do presente estudo foi a de avaliar a distribuição do carbono orgânico total e, secundariamente, o estudo composicional dos folhelhos da Formação Longá na Bacia do Parnaíba. Procurou-se verificar se esta distribuição apresenta relações com a sedimentação, com o tectonismo (no caso o Lineamento Transbrasiliano) e o magmatismo (possível efeito térmico dos eventos magmáticos do Triássico e Cretáceo) da Bacia do Parnaíba. A partir de amostras obtidas quase que exclusivamente em afloramentos, procurou-se obter um quadro geral da distribuição do conteúdo de carbono orgânico total (COT) dos folhelhos da Formação Longá (além de compará-los com os dados disponíveis para os folhelhos da Formação Pimenteiras), bem como sua composição mineralógica essencial.

Os folhelhos da Formação Longá estudados são principalmente rítmicos, em lâminas alternadas com arenitos. Os folhelhos por vezes contêm icnofósseis (icnofácies cruziana). Os arenitos apresentam laminação plano paralela e cruzada, marcas onduladas de corrente e marcas onduladas com padrão de domos e bacias, além de icnofósseis. Localmente as intercalações de arenito são mais espessas, com camadas da ordem de alguns metros.

Os folhelhos da Formação Longá das faixas de afloramentos leste e oeste apresentam composições mineralógicas distintas. Na faixa leste são compostos por quartzo, albita, mica, clorita, calcita, dolomita e hematita. Na faixa oeste são compostos por feldspato potássico e caulinita, além de quartzo, mica, clorita, interestratificado illita/smectita e calcita. Curiosamente o quartzo não foi detectado em algumas amostras da Formação Longá, provenientes das faixas leste e oeste de afloramentos. A presença de caulinita parece estar restrita a porções sujeitas a algum intemperismo. Interestratificados I/S tendem a estar preservados em porções não alteradas dos perfis. Clorita e mica detríticas apresentam distribuição generalizada. A hematita é um constituinte deposicional ou neoformado, em qualquer caso sob condições oxidantes. A albita é autigênica e sua formação pode ter sido influenciada pela atividade magmática da Formação Sardinha, seja por efeito térmico e/ou de circulação de fluídos. Pode ainda resultar da substituição de feldspato potássico por soterramento, que teria sido maior na parte leste da Bacia do Parnaíba. 
As amostras de folhelhos da Formação Longá analisadas apresentaram teores de COT muito baixos para serem consideradas como geradoras de hidrocarbonetos. Na faixa de afloramentos leste da Bacia do Parnaíba os folhelhos apresentaram valores de COT entre $0,33 \%$ e $0,02 \%$, enquanto que na faixa de afloramentos da parte oeste da bacia os teores de COT variaram entre $0,61 \%$ e $0,05 \%$. Os maiores teores de COT encontrados na Formação Longá estão em amostras que apresentam calcita e dolomita, o que sugere maior preservação ao intemperismo. As amostras com teor mais baixo contém hematita, que pode ser constituinte deposicional ou autigênica, neste caso relacionada a processos superficiais.

Para a Formação Longá não há relação evidente entre os teores de COT e a proximidade de rochas básicas intrusivas. Entretanto, as amostras com teores mais baixos encontram-se na área de influência do Lineamento Transbrasiliano.

Os folhelhos da Formação Pimenteiras estudados na borda oeste da bacia compõem pacotes de espessura métrica e são compostos por albita, mica, caulinita calcita e dolomita. O quartzo não foi detectado em todas as amostras da Formação Pimenteiras. A presença de pirita detrítica indica a vigência de condições anóxicas durante a deposição.

Os valores de COT obtidos em amostras de folhelhos de folhelhos da Formação Pimenteiras, coletadas na faixa oeste de afloramentos, variaram de $0,68 \%$ a $1,55 \%$, muito inferiores aos valores de $2 \%$ a até $6 \%$ reportados para a parte leste da bacia. Os menores teores da faixa oeste podem estar relacionados com a proximidade do Lineamento Transbrasiliano.

A natureza siliciclástica dos folhelhos da Formação Longá mostra uma origem a partir de porções emersas do Gondwana que estavam sendo erodidas durante a deposição, a qual teria ocorrido sob clima temperado, em ambiente nerítico. As mudanças climáticas certamente afetaram a produção de biomassa e consequentemente a quantidade de matéria orgânica presente nos folhelhos das formações devonianas estudadas.

Os dados obtidos neste trabalho representam uma visão geral da distribuição do carbono orgânico total e da composição dos folhelhos da Formação Longá. Há recorrência vertical dos níveis de folhelhos, com diferentes teores de COT, bem como 
variações laterais desses teores. Desta forma, a melhor avaliação da Formação Longá requer estudos de detalhe com controle estratigráfico mais detalhado. 


\section{Referências bibliográficas}

Albuquerque O.R. \& Dequech V., 1946. Contribuição para a geologia do meio-norte, especialmente Piauí e Maranhão, Brasil. In: Congresso Pan-Americano de Engenharia de Minas e Geologia, 2, Petrópolis, RJ. Anais, Rio de Janeiro, v.3, p. 69-108.

Almeida, F.F.M. de \& Carneiro, C.D.R., 2004. Inundações marinhas fanerózoicas no Brasil e recursos minerais associados. In: Mantesso Neto, V.; Bartorelli, A.; Carneiro, C.D.R.; Brito-Neves, B.B., orgs., Geologia do Continente SulAmericano: Evolução da obra de Fernando Flávio Marques de Almeida. Becca, São Paulo, p.

Alves D.B. \& Rodrigues R., 1985. Infuência das intrusões ígneas nos folhelhos devonianos da Bacia do Baixo Amazonas. Revista Brasileira de Geociências $15: 110-115$.

Beurlen K., 1965. Observações no Devoniano do Estado do Piauí. Anais da Academia Brasileira de Ciências 37:61-67.

Bigarella J.J., 1973. Paleocorrentes e deriva continental (comparação entre África e América do Sul). Boletim Paranaense de Geociências 31:141-224

Brindley G.W. \& Brown G., 1980. Crystal Structures of Clay Minerals and their X-ray Identification. Mineralogical Society, $495 \mathrm{pp}$.

Boles J.R., 1982. Active albitization of plagioclase, Gulf Coast Tertiary. American Journal of Science, 282:165-180.

Caputo, M.V., 1984. Stratigraphy, tectonics, paleoclimatology and paleogeography of northern basins of Brazil. PhD Thesis, University of California, $583 \mathrm{p}$.

Caputo, M.V. \& Lima E.C., 1984. Estratigrafia, idade e correlação do Grupo Serra Grande - Bacia do Parnaíba. In: Congresso Brasileiro de Geologia, 33, Rio de Janeiro. Anais, SBG, v.2, p. 740-759

Carozzi A.V., Falkenhein F.U.H., Carneiro R.G., Esteves F.R., Contreiras C.J.A., 1975. Análise ambiental e evolução tectônica sinsedimentar da seção siluro-eocarbonífera da Bacia do Maranhão. Ciência-Técnica-Petróleo 7:15-27.

Chamani M.A.C., 2011. Tectônica intraplaca e deformação sinsedimentar induzida por abalos sísmicos: o Lineamento Transbrasiliano e estruturas relacionadas na Província Parnaíba, Brasil. Dissertação de Mestrado, Instituto de Geociências, Universidade de São Paulo, 206 p. 
Conceição J.C.J., Zalán P.V., Dayan H., 1993. Deformações em rochas sedimentares induzidas por intrusões magmáticas: classificação e mecanismos de intrusão. Boletim de Geociências da Petrobras 7:57-91.

Cordani U.G., Neves B.B.B., Fuck R.A., Porto R., Thomaz Filho A., Cunha F.M.B., 1984. Estudo preliminar de integração do Pré-Cambriano com os eventos tectônicos das bacias sedimentares brasileiras. Ciência-Técnica-Petróleo 15, 70 pp.

Cooper P., 1977. Paleolatitudes in the Devonian of Brazil and the Frasnian-Famennian mass extinction. Paleogeography, Paleoclimatology, Paleoecology 21:165-207.

Cunha F.M.B., 1986. Evolução paleozóica da Bacia do Parnaíba e seu arcabouço tectônico. Dissertação de mestrado, Universidade Federal do Rio de Janeiro, 118 p.

Delgado I.M., Souza, J., Silva, L.C., Silveira Filho N.C., Santos R.A., Pedreira A.J., Guimarães J.T., Angelim L.A.A., Vasconcelos A.M., Gomes I.P., Lacerda Filho J. V., Valente C.R., Perrota M.M., Heineck C.A., 2003. Geotectônica do Escudo Atlântico. In: Bizzi L.A., Schobbenhaus, C., Vidotti, R.M., Gonçalves, J.H. Geologia, tectônica e recursos minerais do Brasil. CPRM. 227-334p.

Della Fávera, J.C. 1990. Tempestitos da Bacia do Parnaíba. Tese de Doutoramento, Universidade Federal do Rio Grande do Sul, 590 p.

Destro N., Szatmari P., Ladeira E.A. 1994. Post-Devonian transpresional reactivatio of a Proterozoic dcutile shear zone in Ceará, NE Brazil. Journal of Strutural Geology, $16: 35-45$.

Fleet, M.E., 1998. Detrital pyrite in Witwatersrand gold reefs: X-ray diffraction evidence and implications for atmospheric evolution. Terra Nova, 10:302-306.

Góes A.M., Souza J.M.P., Teixeira L.B., 1990. Estagio Exploratório e Perspectivas Petrolíferas da Bacia do Parnaíba. Boletim de Geociências da Petrobrás 4:55-64.

Góes A.M.O., Travassos W.A.S., Nunes K.C., 1993. Projeto Parnaíba - reavaliação da bacia e perspectivas exploratórias. Belém, Petrobrás. v.1 (relatório interno).

Góes A.M.O. \& Feijó, F.J., 1994. Bacia do Parnaíba. Boletim de Geociências da Petrobras 8:57-67.

Góes A.M., 1995. Formação Poti (Carbonífero Inferior) da Bacia do Parnaíba. Tese de Doutoramento. Universidade de São Paulo, 204 p.

Goldstein J. \& Newbury D.E., 1992. Scanning Electron Microscopy and X-Ray Microanalysis- A text for biologist, Materials Scientist and Geologists., Plenum, New York, 820 p. 
Helmold K.P., van de Kamp P.C., 1984. Diagenetic mineralogy and controls on albitization and laumontite formation in Paleogene arkoses, Santa Inez Mountais, California. In: McDonald D.A. \& Surdam R.C., eds., Clastic Diagenesis. American Association of Petroleum Geologists, Memoir 37:239-276.

Jenkins R. \& Snyder R.L., 1996. Introduction to X-ray powder diffractometry. John Wiley, 403 p.

Johnson J.E., Gerpheide, A., Lamb M.P., Fischer W., 2014. O2 constraints from Paleoproterozoic detrital pyrite and uraninite. Geological Society of America Bulletin, publicado online em 27 de fevereiro de 2014, doi:10.1130/B30949.1

Kegel W., 1953. Contribuição para o estudo do Devoniano da Bacia do Parnaíba. Rio de Janeiro, Departamento Nacional da Produção Mineral, Divisão de Geologia e Mineralogia, $48 \mathrm{p}$.

Lima Filho, F.P., 1991. Fácies e ambientes deposicionais da Formaçã̃ Piauí (Pensilvaniano), Bacia do Parnaíba. Dissertação de Mestrado. Universidade de São Paulo, 137p.

Lima Filho F.P., 1998. As sequências permo-pensilvanianas da Bacia do Parnaíba. Tese de Doutoramento, Universidade de São Paulo, 166 p.

Lobato G. \& Borghi L., 2007. Análise estratigráfica de alta resolução do limite formacional LongálPoti, Bacia do Parnaíba - Um caso de investigação de possíveis corpos isolados de arenitos. Anais. IV Congresso Brasileiro de P\&D em Petróleo e Gás. Campinas, SP.

Mabesoone JM., 1994. Sedimentary basins of Northeast Brazil. Universidade Federal de Pernambuco, 308 p.

Martín, V. P. 1999. DRXWin \& CreaFit 2.0: Graphical and Analytical Tools for Powder XRD Patterns, Powder Diffraction, 14:70-73.

Marzoli A., Renner P.R., Piccirillo E.M., Ernesto M., Bellieni G., De Min A., 1999. Extensive 200-million-year-old continental flood basalts of the Central Atlantic Magmatic Province. Science 284: 616-618.

Mizusaki A.M.P. \& Thomas-Filho, A. O . 2004. O magmatismo pós-paleozóico no Brasil. In: Mantesso Neto, V.; Bartorelli, A.; Carneiro, C.D.R.; Brito-Neves, B.B., orgs., Geologia do Continente Sul-Americano: Evolução da obra de Fernando Flávio Marques de Almeida. Becca, São Paulo, p.

Nunn J.A. \& Aires J.R., 1988. Gravity Anomalies and Flexure of the Lithosphere at Middle Amazon Basin. Journal of Geophysical Research, 93:415-428. 
Ormö J., Komatsu G., Chan M.A., Beitler B., Parry W.T., 2004. Geological features indicative of processes related to the hematite formation in Meridiani Planum and Aram Chaos, Mars: a comparison with diagenetic hematite deposits in southern Utah, USA. Icarus 171: 295-316.

Oshchudlak M.E, Hubert J.H., 1988. Petrology of Mesozoic sandstones in the Newark basin, central New Jersey and adjacent New York. In: Manspeizer W., ed., Triassic-Jurassic rifting, continental breakup and the origin of the Atlantic Ocean and passive margins, part A. Elsevier, Developments in Geotectonics, v.22, p. 333352.

Park Y.A., Pilkey O.H., 1981. Detrital mica: environmental significance of roundness and grain surface textures. Journal of Sedimentary Petrology 51: 113-120.

Parrish J.T., 1998. Interpreting pre-Quaternary climate from the geologic record. New York, Columbia University Press, 338 pp.

Ribeiro J.A.P. \& Melo F., 1996. Os sistemas deposicionais na Bacia do Parnaíba e a o norte de Teresina, Piauí. Revista de Geologia, 9:53-73p.

Rodrigues R., 1995. Geoquímica Orgânica na bacia do Parnaíba. Tese de Doutoramento, Universidade Federal do Rio Grande do Sul, 225p.

Rosseti D.F., Goés A.M. \& Truckenbrodt W., 2001. O Cretáceo da Bacia de São LuísGrajaú. Belém, Museu Emílio Goeldi, 246p.

Rouchon V., Orberger B., Hofmann A., Pinti D. L., 2009. Diagenetic Fe-carbonates in Paleoarchean felsic sedimentary rocks (Hooggenoeg Formation, Barberton greenstone belt, South Africa): Implications for $\mathrm{CO} 2$ sequestration and the chemical budget of seawater. Precambrian Research, 172:255-278.

Saigal G.C., Morad S., Bjieirlykke K., Egeberg P.K., Aagaardgirish P., 1988. Diagenetic albitization of detrital K-feldspar in Jurassic, Lower Cretaceous, and Tertiary clastic reservoir rocks from offshore Norway, I, textures and origin. Journal of Sedimentary Petrology 58: 1003-1013.

Santos M. E., Carvalho M. S., 2009. Paleontologia das bacias do Parnaíba, Grajaú e São Luís. CPRM DGM/DIPALE 215p.

Schrag D.P., Berner R.A., Hoffman P.F., Galen P.H., 2002. On the initiation of a snowball Earth. Geochemistry. Geophysics. Geosystem, 3:1-21.

Schobbenhaus C., Campo D.D., Derze G.R., Asmus H. E., 1984. Mapa geológico do Brasil e da área oceânica adjacente incluindo depósitos minerais. Escala 1: 2.500.000, Departamento Nacional da Produção Mineral, Brasilia. 
Sepkoski J.J., 1990. Evolutionary faunas. In: Briggs D.E. \& Crowther P.R. Paleobiology, a synthesis. 37-41 p.

Tissot B. \& Welte D.H., 1984. Petroleum Formation and Ocurrence. Springer Verlang, $699 \mathrm{p}$.

Torsvik T.H., Cocks L.R.M., 2011. The Palaeozoic palaeogeography of central Gondwana. In: Van Hinsbergen D.J. J., Buiter S.J.H., Torsvik T.H., Gaina C. \& Webb S.J. The Formation and Evolution of Africa: A Synopsis of $3.8 \mathrm{Ga}$ of Earth History. Geological Society, London, Special Publications, 357:137-166.

Vaz P.T., Rezende N.G.A.M., Wanderley Filho J.R., Travassos W.A.S., 2007. Bacia do Parnaíba. Boletim de Geociências da Petrobras, 15:253-263.

Whitting L.D. 1965. X-ray Diffraction Techniques. In: Klute, A. Methods of soil analysis, part 1. Physical and Mineralogical Methods. Madison. American Society of Agronomy, 12:331-362.

Zalán, P. 2004. Evolução Fanerozoica das Bacias Sedimentares Brasileiras. In: Mantesso Neto, V.; Bartorelli, A.; Carneiro, C.D.R.; Brito-Neves, B.B., orgs., Geologia do Continente Sul-Americano: Evolução da obra de Fernando Flávio Marques de Almeida. Becca, São Paulo, p. 
ANEXO 
Dados de campo e relação de amostras 
